\title{
Study of the chemical composition and the mechanical behaviour of 20th century commercial artists' oil paints containing manganese-based pigments
}

\author{
Laura Fuster-Lopez ${ }^{1}$, Francesca Caterina Izzo ${ }^{2 *}$, Marco Piovesan² $^{2}$, Dolores J. Yusa-Marco ${ }^{1}$, \\ Laura Sperni $^{3}$, Elisabetta Zendri ${ }^{2}$
}

1. Universidad Politécnica de Valencia, Departamento de Conservación- y Restauración de Bienes Culturales, Camino de Vera s/n, 46022, Valencia, Spain.

2. Ca' Foscari University of Venice, Department of Environmental Sciences, Informatics and Statistics, Via Torino 155/b, Venice

3. Ca' Foscari University of Venice, Department of Molecular Sciences and Nanosystems, Via Torino 155/b, Venice

* Corresponding author: fra.izzo@unive.it, 0039-0412346730 (T), 0039-0412346729 (F)

\begin{abstract}
The present study deals with $20^{\text {th }}$ century manufactured artists' oil paints containing raw and burnt umber pigments, this is, natural earth pigments resulting from the combination of iron and manganese oxides. Manganese, in particular, is known to be a primary drier and to have a siccative effect on oil paint films.

This research aims to show the diversity of formulations behind apparently same commercial names as well as to understand how the content of manganese, the presence of modern lipidic media and the hydrolysis mechanisms can promote significant differences in the expected mechanical properties of oil paint films, thus conditioning their long-term performance.

Several manufactured artists' oil paint films containing manganese were selected. Dried films from raw and burnt umber oil paints by Winsor\&Newton ${ }^{\circledR}$ (UK), $\operatorname{Grumbacher}^{\circledR}$ (USA), Gamblin ${ }^{\circledR}$ (USA) and Speedball ${ }^{\circledR}$ (USA) were studied and information about their chemical composition and mechanical behaviour is here presented. In addition to the identification and the study of the inorganic and organic components present in each formulation through LM, SEM-EDX, FTIR-ATR, XRD, GC-MS analysis, tensile tests were run and stress-strain curves were obtained. Together with evident hue differences, the obtained results showed significant differences in the chemical composition and the mechanical behaviour of the oil paint films.
\end{abstract}

Keywords: Modern oil paint, commercial formulations, manganese, umbers, mechanical properties, hydrolysis, FTIR, SEM-EDX, FTIR-ATR, XRD, TG-DSC, GC- MS.

\section{Introduction}


Modern and contemporary paintings are facing complexities not only due to the nature of materials and their ageing and response to environment conditions, but also derived from the interactions which different materials may experience in the context of a painted structure. From this perspective and considering the variety of industrial formulations produced since the late $19^{\text {th }}$ century, it is evident that the identification of specific damages in modern and contemporary painted surfaces is not easily ascribable to a single cause but to the synergic situations (even under strictly controlled environmental conditions). This suggests the need of combining the chemicalphysical characterisation and the study of mechanical and dimensional properties of painting materials to understand failure mechanisms and to design the appropriate conservation strategies. The topic of the current research is the investigation of $20^{\text {th }}$ century manufactured oil paints containing manganese-based pigments, such as Raw and Burnt umbers.

The growing interest around the study of the nature of $20^{\text {th }}$ century artists' oil paints arose in the last decade to increase the knowledge related to modern and contemporary art materials and to respond to practical conservation issues. In particular, the investigation of manufactured oil paints was essential to understand the vulnerability observed in several well-bound oil paints from unvarnished artworks [1-5]. Recent studies highlighted the possible correlations between the degradation phenomena exhibited by modern oil paintings and $20^{\text {th }}$ Century oil paint formulations, focusing in particular on the variety of vegetable oils used and the various organic additives typically introduced by paint manufacturers [6-7].

A fundamental role in the drying mechanism of commercial oil films is played by the presence of pigments. Umbers (both the natural/raw and the calcinated/burnt forms) are natural earth pigments composed of mixtures of iron and manganese oxides [8-11]. Previous studies showed that iron oxides have an inhibiting effect on the oxidative polymerization of the drying oils [12] and accelerate the formation of scission products by photo-oxidation [13].

Generally, paint films containing earth pigments are extremely flexible, weak [14] and sensitive to moisture [15-17]. The clay content in earth-based oil paint films is the reason for their ability to absorb water and undergo severe swelling, even with moderate oscillations of relative humidity. It has been proved that paint films containing umbers experience a significant dimensional response with high levels of relative humidity (between $75 \%$ and $90 \% \mathrm{RH}$ ), with both linseed and safflower oil media [15]. Under these conditions, umbers are flexible and elongable at break and present a very low ultimate tensile strength [16].

However, manganese is also a primary drier and therefore manganese-based pigments are known to have a siccative effect on oil paint films [18-21]. During the oxidation reaction in film forming, the ion $\mathrm{Mn}^{2+}$ exerts through-drying properties which promote surface drying in the curing of oil paints. During hydrolysis of an oil film, free fatty acids are released and can migrate in the oil, reacting with metal ions present in the pigment and leading to the formation of metal soaps. As reported in [22], the greater amount of manganese oxides is present, the higher percentages of manganese ions dissociate from these oxides and dissolve in the oil accelerating its drying. Finally, an increase in the amount of manganese ions result in an increased stiffness of the paint film. The intrinsic characteristics of umbers and their interactions with the binding media govern paints performance and stability in mid-to-long terms, being also responsible for paints specific ageing and vulnerability. 
Based on the above mentioned previous researches, this study addresses the issues related to the chemistry and the mechanical behaviour of $20^{\text {th }}$ century raw and burnt umber oil paint films. The present research, in fact, correlates the chemical composition and the mechanical properties observed for selected manufactured umber oil paint films after being naturally aged for several decades, aiming to understand the influence of manganese in the formation of oil films, the role of manganese in paint films' mechanical behaviour and the way in which paint films containing manganese may perform in the mid-to-long term in the context of a painted structure.

\section{Materials and methods}

\subsection{Paint samples and sample preparation}

All the paints tested in this study belong to the Mecklenburg's Paint Reference Collection at the Smithsonian Center for Materials Research and Education (USA). The selected raw and burnt umbers paints were manufactured by Winsor\&Newton ${ }^{\circledR}(\mathrm{W} \& N)$, Gamblin $^{\circledR}$, Speedball ${ }^{\circledR}$ and Grumbacher $^{\circledR}$. The oil films tested and discussed in this paper were prepared in the 1980's and 1990's on polyester film and allowed to dry in controlled environmental conditions during a period ranging from 15 to 35 years.

\section{< place Table 1a here>}

\section{< place Figure 1 here $>$}

Table 1a reports a detailed description of the commercial oil paint films, which are showed in Figure 1.

The composition of these paint films was studied during this research (in 2014). Their mechanical behaviour was also tested during this study, but further discussion was possible by comparing the stress-strain curves obtained in 2014 with those obtained from the same films in 2003 and reported in [17].

Two white oil films, prepared for the Mecklenburg's Paint Reference Collection by mixing pigments in cold pressed linseed oil (CPLO) [14] were additionally used for comparing the mechanical behaviour of manganese-containing film. Since lead white in CPLO is known to provide stiff and tough films and zinc white in CPLO presents a brittle behaviour, the aim of such comparison was to provide a broad understanding of the plasticity of the different umber paint films tested in this study. Their details are reported in Table $1 \mathrm{~b}$.

\section{< place Table 1b here >}


The thickness of the different paint films was measured with a Mitutoyo ${ }^{\circledR} 103-137$ micrometer. Except for the Speedball ${ }^{\circledR}$ paint sample, the thickness of the free unsupported paint films was around $0.25 \mathrm{~mm}( \pm 8 \%)$.

\subsection{Analytical techniques and methods}

The commercial oil films were chemically and mechanically studied by the joint use of several analytical techniques to obtained data about the composition of the inorganic and organic fractions, their morphology, and the mechanical behaviour.

Microsamples were taken from the dried films and firstly examined under a Leica DMR microscope using reflected light at the $25 \times$ to $400 \times$ magnification.

Surfaces and cross sections of the film specimens were observed using a Jeol JSM 6300 scanning electron microscope operating with a Link-Oxford-Isis energy-dispersive X-ray microanalysis system. The analytical conditions were $20 \mathrm{kV}$ accelerating voltage, 2.10-9A beam current and 15 $\mathrm{mm}$ distance. Samples were carbon-coated to eliminate charging effects. Elemental semiquantitative weight percentages were calculated by EDX analysis according to ZAF matrix correction) [23-24].

FTIR-ATR analyses were performed with a Thermo Nicolet Nexus 670 FTIR spectrophotometer combined with a Smart Orbit Single Reflection Diamond ATR accessory, from 4000 to $400 \mathrm{~cm}^{-1}$ for 64 scans with $4 \mathrm{~cm}^{-1}$ resolution. Spectra were elaborated with Omnic 10.0 and Origin 9.0 softwares.

To identify organic binders and additives, the oil samples were transestherified using (trifluoromethylphenyl) trimethylammonium hydroxide, overnight reaction as described in [25-26]. GC-MS analysis was performed using a Trace GC 2000 instrument with a capillary Supelco Equity-5 column, 30 m, 0.25 mm, 0.5 um interfaced with Trace MS 2000 (Thermo Finningan). The inlet temperature was $300^{\circ} \mathrm{C}$, the MS interface was at $270^{\circ} \mathrm{C}$. The temperature program was set from $80^{\circ} \mathrm{C}$ to $300^{\circ} \mathrm{C}$ with a ramp of $10^{\circ} \mathrm{C} / \mathrm{min}$, held at $300^{\circ} \mathrm{C}$ for 2 minutes. The MS was run in Full Scan mode ( $\mathrm{m} / \mathrm{z} 40-600), 1.9 \mathrm{scans} / \mathrm{sec}$. Solvent delay was set at $4.5 \mathrm{~min}$. The transfer line was at $240^{\circ} \mathrm{C}$ and the source temperature was $220^{\circ} \mathrm{C}$. Electron Ionisation energy was $70 \mathrm{eV}$. Quantitative GC-MS analysis was performed using nonadecanoic acid as internal standard.

The molar ratios among the most significant fatty acids were calculated: palmitic to stearic acid $(\mathrm{P} / \mathrm{S})$, azelaic to palmitic acid $(\mathrm{A} / \mathrm{P})$, oleic to stearic acid $(\mathrm{O} / \mathrm{S})$ ratios were considered and compared to previous results obtained by the authors on 20th century artists oil paints as described in $[7,26]$.

Physical properties measurements were conducted using custom built miniature tensile testers [27]. Average sample measurements were $5 \mathrm{~mm}$ (width) $\times 0.25 \mathrm{~mm}$ ( $\pm 8 \%$ ) (thickness) and 20-mm (length). Umbers and white samples from the same paint strips casted in the 1990's and tested by Mecklenburg et al. in the very early stages of their drying process [17], were again tested for this study thus allowing the monitoring of changes induced after having been drying for 15 years in a 
controlled environment. For this purpose the polyester film was removed and the tests were run on free unsupported paint films. The specimens were mounted in testing gauges and conditioned in the chamber for $48 \mathrm{~h}$ at $50 \pm 0.5 \% \mathrm{RH}$ and $23 \pm 0.5^{\circ} \mathrm{C}$ prior to testing. All the tests were conducted at the same strain rate and after the paints had fully equilibrated to the environmental conditions indicated.

\section{Results and discussion}

\subsection{Chemical characterization}

This section presents the results from the study of the organic and inorganic fractions of the selected paint samples. Some considerations regarding the oxidation state of the paint samples are also reported.

\subsubsection{Inorganic fraction}

The results related to the inorganic fraction are reported in Tables 2 and 3.

\section{< place Table 2 here> \\ $<$ place Table 3 here $>$}

Analysing the composition of W\&N, Grumbacher and Gamblin raw umbers films and taking into consideration the most meaningful elements detected by EDX analysis (such as $\mathrm{Fe}, \mathrm{Mn}, \mathrm{Ca}$ and $\mathrm{Si}$ Table 3), some considerations can be done:

- a significant presence of iron was detected; it ranges from $16 \%$ in WN-RU (due only to the presence of goethite, $\alpha-\mathrm{FeOOH}$ ) to 29.9 and $35.3 \%$ in GA-RU and GR-RU respectively (linked to the presence of both goethite and iron oxide (III), $\mathrm{Fe}_{2} \mathrm{O}_{3}$ );

- the manganese content varies from 3.2\% (GA-RU) to 6.6\% (GR-RU) : it is present in the three commercial paints as pyrolusite $\mathrm{MnO}_{2}$, the typical manganese oxide present in umbers;

- WN-RU and GR-RU showed a similar content of calcium (15 and $15.8 \%$ respectively) which derives from the presence of calcite $\mathrm{CaCO}_{3}$ and calcium phosphate $\mathrm{Ca}_{3}\left(\mathrm{PO}_{4}\right)_{2}$; dolomite $\mathrm{CaMg}\left(\mathrm{CO}_{3}\right)_{2}$ was additionally found in $\mathrm{WN}-\mathrm{RU}$; the calcium content in GA-RU derives exclusively from the presence of calcium carbonate;

- the silicon content varies from $4.8 \%$ in WN-RU (only related to the presence of magnesium silicate) to $16.5 \%$ in GA-RU. In the latter, the typical FT-IR absorption bands in the region between $3700-3600 \mathrm{~cm}^{-1}$ (Figure 2) were observed: they correspond to layered silicates typically found in clays, which were further identified by XRD as kaolinite $\left(\mathrm{Al}_{2} \mathrm{Si}_{2} \mathrm{O}_{5}(\mathrm{OH})_{4}\right)$ and illite $\left(\left(\mathrm{K}, \mathrm{H}_{3} \mathrm{O}\right)(\mathrm{Al}, \mathrm{Mg}, \mathrm{Fe})_{2}(\mathrm{Si}, \mathrm{Al})_{4} \mathrm{O}_{10}\left[(\mathrm{OH})_{2,}\left(\mathrm{H}_{2} \mathrm{O}\right)\right]\right)$; 
Considering the manufactured burnt umbers oil paints, it can be observed that:

- according to XRD analysis, GA-BU contains three iron-based minerals, namely hematite $\left(\alpha-\mathrm{Fe} 2 \mathrm{O}_{3}\right)$ , magnetite $\left(\mathrm{Fe}_{3} \mathrm{O}_{4}\right)$ and maghemite $\left(\square-\mathrm{Fe}_{2} \mathrm{O}_{3}\right)$, whose presence justified the higher content of iron (38.7\%) in comparison with WN-BU (34.4\%) and GR-BU (31.1\%). SP-BU contains hematite and goethite, but its total iron content is the lowest (25.8\%): this might explain the fact that the SP-BU hue is lighter (see Figure 1);

- generally, the manganese content is higher in burnt umbers than in raw umbers paints, except for the Speedball ${ }^{\circledR}$ paint. In all the paints, manganese oxides were detected by XRD analysis; - the calcium content is similar amongst the four commercial paints and derives from calcite (present in all the paints), dolomite (in WN-BU and SP-BU) and calcium phosphate (in GR-BU and SP-BU);

- the \% of silicon is generally higher than in the corresponding raw umbers; in the case of WN-BU the presence of silicon is completely linked to the presence of quartz, while in the other burnt umbers the contribute of several silicate-based minerals was recorded.

As an example, Figure 3 depicts the XDR diffractograms of Grumbacher ${ }^{\circledR}$ raw and burnt umber oil paints, highlighting the main differences observed amongst the two varieties of umber pigments.

\section{< place Figure 3here >}

The comparison of the iron, manganese, calcium and silicon content between raw and burnt umbers from the same commercial brand is significant to understand how the pigments were produced by the same manufacturer. Since it is likely that the burnt umbers (WN-BU, GA-BU, GR$B U$ ) were not obtained from their corresponding raw umber (WN-RU, GA-RU, GR-RU) through the traditional calcination process, a possible explanation for their different composition is that two umber varieties might have been mixed.

This occurrence may indicate that manufacturers used natural earth-based pigments in the formulation of the paints mixed with different oxides. SEM/EDX images show that iron and manganese oxides are dispersed into the paint matrix as fine particles together with coarse grains mainly composed of silicate and carbonate compounds: see for example Grumbacher ${ }^{\circledR}$ and Speedball ${ }^{\circledR}$ paints images displayed in Figure 4.

\section{< place Figure 4 here $>$}

In fact, although the paints composition recalls the typical composition of traditional umber pigments, the use of natural earths enriched with iron and manganese oxides in the manufacture of paints cannot be excluded. This hypothesis may be explained by the limited natural resources available nowadays as well as the high extraction costs of natural deposits. According to this, the addition of oxides would have enabled manufacturers to vary and control the composition of the pigments, and consequently their coloration, thus ensuring reproducibility in the commercial production of the paints. 
Furthermore, some identified silicate and carbonate compounds might actually be inorganic extenders added in the manufacture process to replace part of pigment volume, thus reducing the costs of raw materials $[28,29]$. The presence of dolomite in $W \& N^{\circledR}$ paints is also reported in other studies which identified this compound as an extender added by the manufacturer [30,31]. Calcite, silicon oxide compounds (particularly quartz) and kaolinite have likely the same function in the other studied paints, being some of the most important inorganic compounds used as extenders in the industrial formulation of $20^{\text {th }}$ century pigments [7].

\subsubsection{Binding medium and organic additives}

The analysis of the manufactured paint films showed that all the examined paints were bound in lipidic media.

Together with the typical IR absorption bands observed in the IR spectra (see figures 4 and 10), all the obtained GC-MS chromatograms show the typical composition of drying oil-based paints in terms of saturated, unsaturated and difatty acids [20]. As an example, figure 5 illustrates the total ion current chromatographs of Grumbacher ${ }^{\circledR}$ raw umber, W\&N ${ }^{\circledR}$ burnt umber and Speedball ${ }^{\circledR}$ burnt umber paint samples, in which the presence of derivatives of glycerol and methyl esters of saturated (palmitic, stearic), dicarboxylic (suberic, azelaic and sebacic) and unsaturated (oleic C18:1) fatty acids is highlighted.

\section{< place Figure 5 here>}

In table 2, the most significant fatty acid molar ratios $(\mathrm{A} / \mathrm{P}, \mathrm{P} / \mathrm{S}, \mathrm{O} / \mathrm{S})$ are reported for all the studied films. While for traditional oil paints, these ratios provide important information about the type of drying oil (based on $\mathrm{P} / \mathrm{S}$ ratios), drying, ageing and oxidation rate (based on $\mathrm{A} / \mathrm{P}$ and $\mathrm{O} / \mathrm{S}$ ratios) $[20,32,33]$, recent studies outlined that these ratios are not completely reliable for modern and contemporary oil paints $[7,26,34]$.

Since $\mathrm{P} / \mathrm{S}$ ratios alone cannot provide absolute proof of the kind of oil in modern formulations due to different contributions which may interfere (e.g. the addition of metal stearates, castor wax, semi drying oils, non-drying oils, etc) $[1,7,26$,$] , the information given by manufacturers and the$ occurrence of any special fatty acids were additionally considered [26, 33, 35]. W\&N declared to use a mixture of linseed and Safflower oils, Grumbacher ${ }^{\circledR}$ and Gamblin ${ }^{\circledR}$ referred to employ alkali refined linseed oil, while Speedball ${ }^{\circledR}$ linseed oil (see Table 1 ).

In the case of Gamblin ${ }^{\circledR}$ and Speedball ${ }^{\circledR}$ paints the $\mathrm{P} / \mathrm{S}$ ratios and a significant amount of arachidic acid indicate a possible mixture of two oils: linseed oil (the traditional medium with known siccative properties with $\mathrm{P} / \mathrm{S}$ ratio of about 1.6) and safflower oil ( $\mathrm{P} / \mathrm{S}$ ratios ranging from 2 to 2.5).

Safflower is a semi-drying oil introduced during the $20^{\text {th }}$ century by the paint industry and widely used alone or in mixture with linseed oil because its lower tendency to yellowing. This oil normally contains a higher amount of arachidic acid than linseed oil [35]. The trading houses usually vary the percentages of the oils mixed to balance the drying properties and to avoid the problem of yellowing of linseed oil [29]. 
In the case of $W \& N \otimes$, the $P / S$ ratios are 1.3 for $W N-R U$ and 1.6 for $W N-B U$, which could be traditionally referred to linseed oil [32]. However, the presence of a mixture of linseed and safflower oil cannot be excluded. From previous studies, it is known that $\mathrm{W} \& \mathrm{~N} \circledast$ uses this specific mixture in their oil paints [7, 29], as they actually declared.

Grumbacher ${ }^{\circledR} \mathrm{P} / \mathrm{S}$ ratios are lower than the traditional values identified for linseed oil $(0.9$ for GR$R U$ and GR-BU). Such values may indicate the presence of metal stearates (in particular aluminium stearates) which were commonly added in the $20^{\text {th }}$ century in paint formulations as dispersing agents $[26,36]$ and can affect the normal P/S values of linseed oil depending on their amount, as reported in other studies $[7,26]$. Their $\mathrm{P} / \mathrm{S}$ ratio is, in fact, $0.5-0.8$. Although it is not possible to make precise assumptions to the amount of added metal stearates in the studied paints, their presence can be confirmed by the characteristic IR absorptions at around 1580 and $1460 \mathrm{~cm}^{-1}$, as observed in Grumbacher ${ }^{\circledR}$ and Gamblin ${ }^{\circledR}$ IR spectra (thus, more than $5 \%$ of the paint mixture, since this is the detection limit of FT-IR technique). The presence of such additives in Grumbacher $®$ and Gamblin ${ }^{\circledR}$ paints may be also correlated with the need to improve the dispersion of pigments after the alkaline refining treatment of the binding medium [37].

The presence of other additives (such as castor wax, or natural waxes as stabilisers) and non-drying oils (such as castor oil as a lubricant) was not detected in the studied films

\subsubsection{Considerations regarding the oxidation state and the condition of the paint samples}

For traditional dried and aged oil paint films, the azelaic/palmitic (A/P) ratios are generally higher than 1 and the oleic/stearic $(\mathrm{O} / \mathrm{S})$ ratios are normally around $0.1-0.2$ [38].

Observing the ratios reported in Table 2, it is possible to make some assumptions about the oxidation state of the studied oil films:

- The A/P ratios for umbers oil films ranged from 1.0 (SP-BU) to 1.8 (GR-BU). Although it would have been expected a higher A/P for the Speedball ${ }^{\circledR}$ paint which was casted in 1981, its thickness (bigger than the other films, see Table 1) and the different content of manganese and iron-based compounds are probably the responsible for having the lowest A/P ratio.

The A/P ratios are in fact known to be strictly dependent on various factors, such as the oxidation state, the availability of oxygen, the degradation and the level of polymerisation, the thickness and the age of the film, etc. Moreover, as seen for $\mathrm{P} / \mathrm{S}$ ratios, $\mathrm{A} / \mathrm{P}$ ratios can be influenced by the presence of dispersing agents such as aluminium stearates, which contain not only stearates but also palmitates $[7,26]$.

- The O/S ratios indicate that all the samples present a significant degree of oxidation. In the case

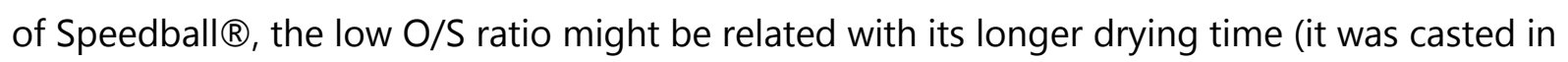
1981) compared to the other commercial paints studied (casted in 1999). Higher ratios can be observed in $\mathrm{W} \& \mathrm{~N} 囚$, which is indicative of less mature paint films for a same given drying time. However, these comparisons between different paint films are not completely reliable since -even within the same type of drying oil- the initial quantity of oleic, stearic and palmitic acids may be 
different. Again, $\mathrm{O} / \mathrm{S}$ ratios can be influenced by the presence of mixtures of oils as well as by dispersing agents.

- Comparing the FT-IR spectra, it can be noticed that there is a pronounced absorption band visible at approximately $1710 \mathrm{~cm}^{-1}$ (see figure 4 and 10; note in particular the second derivative of the latter IR spectrum). This absorption is due to the stretching vibration of $\mathrm{C}=\mathrm{O}$ of the carboxyl group of free fatty acids. These acids are always present in a drying oil as secondary components and/or added as free carboxylates (eg. metal stearates) but they may increase during ageing as a result of degradation phenomena such as hydrolysis, with consequent enhancement of the carboxylic band [39]. It might be assumed that some of the oil paint films studied may have undergone hydrolysis over time, with release and consequent increase of free fatty acids in the oil and the formation of metal soaps. This problem seems to be frequent in earth-based oil paint films. In previous studies [22], it was already stated that paints containing earths, such as umber, ochre, and sienna, tend to hydrolyze in a very short time. Despite it is not clear why this phenomenon of degradation of the oil can take place more easily in the presence of such pigment, it could probably be related to the hygroscopicity of the clay and silicates they contain, and their ability to absorb moisture.

Besides the possible addition by manufacturers of metal stearates, the presence of metal soaps detected by GC-MS ratios and FT-IR analysis can differently/also be associated to metal soaps containing manganese. These compounds may have formed by the reaction between free fatty acids (increased due to the possible hydrolysis phenomena mentioned above) and the metal ions from the oxides dissociated in the oil. As reported in [18], hydrolysis -and the resulting release of free fatty acids, increases the acidity of the oil and consequently its ability to dissolve partially the oxides of manganese. By increasing the contact time between the oil and such oxides, more manganese ions dissolve and migrate in the oil where they are able to accelerate its drying process and react with the free fatty acids leading to the formation of metal soaps.

Moreover, as seen in previous studies, the presence of iron oxides (such as those found in all the manufactured umbers studied) may inhibit the effect on the oxidative polymerization of the drying oils and then accelerate the formation of scission products by photo-oxidation $[12,13]$. This could be the case of GR-RU and GR-BU, in which the content of iron (present as iron oxide (III), goethite and hematite) is more than $30 \%$, as reported in Table 3.

\subsection{Study of the mechanical properties of raw and burnt umber oil paint films}

The mechanical properties and dimensional response of oil paint films are governed by the interaction between pigments and media. Previous researches showed that, with some exceptions, the stiffness and strength of oil paint films tend to increase during ageing whereas the strain to failure decreases progressively. One of these exceptions are earth-based paint films.

Figure 6 represents the different stress-strain curves of the studied raw and burnt commercial umbers together with those of different white paint samples (see 2.1, Table 1b). It provides an interesting insight into the specific behaviour of umbers as well as the role played by pigments in their mechanical properties. In this figure, lead white in CPLO represents a durable, strong and stiff 
oil paint film whereas zinc white CPLO paint film represents the stiffness that some oil paints can achieve over time.

< place Figure 6 here>

Mecklenburg et al. also showed that the presence of siccatives (i.e.: litharge)- even in small amount, speeds up oil paints drying but also induce significant changes in their mechanical properties $[14,15,27]$.

According to this, the particular mechanical behaviour observed in the studied umber paint films can be explained as a function of the nature of the pigment and the composition and refining processes which oil underwent. In addition, the early hydrolysis umbers experience during drying strongly influence the film forming process in all the studied paints and determine their plastic behaviour.

\subsubsection{The influence of the inorganic fraction of umbers in their mechanical properties.}

The intrinsic nature of earth pigments influences the mechanical properties of oil paint films in two ways.

On the one hand, the clay content induces severe swelling in earth-based paint films making them become extremelly weak and dimensionally responsive to moisture and therefore vulnerable to humid environments as well as to solvent action [14]. The plastic behaviour of clays is also due to their typical layered silicate structure. Layered silicates (e.g. kaolinite and illite) were found in GA$\mathrm{RU}$ and this could help explain the greater plastic region of this sample in comparison to that of Grumbacher ${ }^{\circledR}$ which does not contain layered silicates (Table 2).

On the other hand, previous studies have shown that the presence of siccative pigments can induce significant changes in the mechanical properties of oil paint films. This study evidenced that the higher content of manganese the stiffer the paint film is. This is true for both raw and burnt umbers.

Figure 7 presents the stress strain curves for the different commercial raw and burnt umbers naturally aged.

$W \& N \otimes$ paints were not mechanically tested since they were extremely weak and broke easily when cutting the samples for testing.

\section{< place Figure 7 here>}

The greater the amount of manganese oxides in the pigment is, the higher the percentage of manganese ions able to dissociate themselves from such oxides and dissolve in the oil, where they exert their siccative action. This results in a higher stiffness of those paint films with higher percentages of manganese. As shown in figure 7, Grumbacher ${ }^{\circledR}$ paint films -characterized by a 
higher percentage of manganese (6.6\% in GR-RU and $11.6 \%$ in GR-BU)- are stiffer than Gamblin ${ }^{\circledR}$ ones (whose content of $\mathrm{Mn}$ is $3.2 \%$ in GA-RU and $6.2 \%$ in GA-BU) .

Equally relevant, by catalyzing the polymerization, a faster crosslinking of fatty acid chains takes place and therfore paints' drying is speeded up.

\section{< place Table 4 here>}

The higher content of manganese may have accelerated the process of polymerization of the oil in Grumbacher ${ }^{\circledR}$ paint samples. The higher content of manganese would have also resulted in a higher elastic modulus. These observations are in agreement with previous studies where an increase of the stiffness was observed with an increasing amount of manganese ions present in the oil paint films $[17,22]$.

Equally interesting is the superposition of raw and burnt umbers stress strain curves which evidences significant trends (Figure 7). Even if the strength at break is extremely low in all cases, and a similar ability to elongate is also evident for raw and burnt umbers, GA-BU and GR-BU, are about four times stronger and twice stiffer than their corresponding raw ones, GA-RU and GR-RU. Speedball ${ }^{\circledR}$, the weakest burnt umber tested, is even stronger and stiffer that any of the commercial raw umber studied but less elongable at break.

It is also interesting to note that umbers present a high oil absorption index, which means that require a high amount of medium to grind (up to $80 \%$ ) and some studies suggested that this is the reason for their tendency to become darker with age [40]. The highly absorbency of umbers together with the fact that Gamblin ${ }^{\circledR}$ and Speedball ${ }^{\circledR}$ present the lower \% content of manganese in their composition as well as a mixture of linseed oil together with a slow drying oil like safflower, could also help explain why they were still soft and even sticky whereas the rest of the paint samples studied were completely dry after similar drying times (see Table 5).

\section{< place Table 5 here $>$}

Finally, the selected paint samples were already tested and analyzed in the early years of their drying process. As displayed in Figures 8 and 9, this comparison allowed to monitor the changes occurred during the last 15 to 35 years (depending on the paint film) in the chemical composition and the mechanical properties of the selected paint films.

\section{$<$ place Figure 8 here> \\ $<$ place Figure 9 here $>$}

\subsubsection{The influence of the organic fraction of umbers in their mechanical properties}

Regarding to the influence of the organic composition in the mechanical properties of the paint films, the different degree of unsaturation of the oils can also be considered. For a same given age (or drying time), the degree of crosslinking of different drying oils depends on the different composition of the unsaturated fatty acids. Fast drying or more siccative oils will give rise to faster cross-linking, being more reactive and viscous, and presenting a greater number of double bonds, 
where radicals attach themselves and where further crosslinking takes place with other fatty acid chains. Moreover, the more cross-linked, the stiffer and stronger the paint film will be.

In the case of the studied paints, a greater crosslinking of the oils could also explain the higher ultimate tensile strength of GR-RU and GR-BU paint samples (Figs. 7 and 8) compared to Gamblin ${ }^{\circledR}$ ones (which seems to be rather more elongable). Speedball ${ }^{\circledR}$ on the contrary, even though it presents a similar elastic modulus than Grumbacher ${ }^{\circledR}$, is significantly weaker and presents a lower elongation at break (figure 8).

As explained previously, a high amount of linoleic acid (doubly unsaturated) typically found in safflower oil as well as a negligible percentage of the more unsaturated linolenic acid (triply unsaturated) typically found in the linseed oil instead were suggested by GC-MS analysis. The analysis evidenced a mixture of linseed and safflower oils in Gamblin ${ }^{\circledR}$ and Speedball ${ }^{\circledR}$ paint films as well as the possible presence of aluminium stearate in both commercial brands that could have been added to reduce the excessive amount of oil needed to wet the pigment $[19,36]$. This could have eventually enhanced the response to moisture of such paint films $[1,3]$. On the other hand, previous studies showed that despite all drying oils respond similarly to $\mathrm{RH}$ oscillations, for a same given pigment some differences in the \% length change were observed as a function of the drying oil present in their composition, being safflower oil the one that experiences the most significant dimensional response, especially with high $\mathrm{RH}$ environments [15].

\subsubsection{The chemical degradation of raw and burnt umber oil paint films and their correlation with changes in the mechanical properties}

The condition of the paint films and the possible presence of hydrolysis phenomenona can be also related to the mechanical behaviour observed.

Generally in the case of umber-based oil films, after an initial fast polymerisation induced by the presence of siccatives such as manganese, the early hydrolysis experienced during drying leads to the increase of weakness and flexibility and the higher the percentage of hydrolysis is, the lower ultimate tensile strength and deformation at break of the paint film [41].

The reduction of the number of chemical bonds that occurs during hydrolysis leads to the formation of a paint film no longer able to resist elongation, which breaks down before it can reach important deformations. This is the case of SP-BU oil paint film.

FT-IR spectra of the three burnt umber paint films (Figure 10) shows a much more significant peak relative to the presence of free fatty acids $\left(\mathrm{ca} .1710 \mathrm{~cm}^{-1}\right.$ ) in the Speedball $\AA$ sample, which presents a lower ultimate tensile strength and elongation at break if compared to GA-BU and GR-BU (Fig. 8). However, despite the weakness caused by hydrolysis as outlined above, Speedball $\circledast$ burnt umber paint film seems to present a similar stiffness to GR-BU (figure 7). The longer drying time of SP-BU paint film (casted in 1981 and therefore naturally aged for 35 years) could probably be one of the reasons for such behaviour.

< place figure 10 here > 
Another interesting issue is the correlation of the mechanical properties of the different samples with the azelaic- palmitic (A/P) ratio obtained by GC-MS analysis. In the case of the burnt umber commercial oil paint films considered in the present study, those samples with a higher A/P ratio were also those with a higher ultimate tensile strength. The same was observed for the raw umbers studied. (Table 4). However, it is necessary to further investigate how A/P ratios correlate with the ultimate tensile strength of oil paint films in order to understand why there was such a big difference in the ultimate tensile strength of samples with very similar A/P ratios (ca. 1.0) (i.e. GA$\mathrm{BU}$ and SP-BU).

\section{Conclusions and future perspectives}

This research was built up on previous studies dealing with the chemistry of $20^{\text {th }}$ century oils and the study of the mechanical and dimensional properties of painting materials, and aimed to provide an insight into the chemistry of selected commercial raw and burnt umber oil paint films, their drying and degradation as well their implications in the changes observed in their mechanical properties during ageing.

The results obtained evidenced:

- The addition of iron and manganese oxides to natural earth pigments to control the composition and colour as well as to reduce production costs;

- the different shades of colour hues for a same given name manufactured by $W \& N \otimes$, Grumbacher $\AA$, Gamblin $\AA$ and Speedball ${ }^{\circledR}$ as a consequence of both the predominance of raw or burnt umber as well as the different composition of binding media used in their production.

- The use of alkaline refined linseed oil or mixtures of linseed and safflower oil.

- The addition of inorganic inert materials as fillers;

- The possible addition of metal soaps to improve the dispersion of pigments in the oil.

By correlating the chemical-physical analysis and the study of the mechanical properties of the selected paint films it was also possible to observe:

- The influence of different drying oils with a different degree of unsaturation in the mechanical properties of paint films; The use of safflower oil -a cheap and slow drying oil used for its low tendency to yellowing- evidenced additional drawbacks in paints' film forming processes; more specifically, the need to further investigate how A/P ratios are correlated with the ultimate tensile strength of the paint film was observed.

- The role of pigments in the mechanical behaviour of the resulting paint films. On the one hand, the eventual clay content is responsible for the dramatic plasticity and vulnerability to moisture (and solvents) of the films. On the other hand, the presence of some siccative pigments such as manganese contributes to make the paint film become stiffer in time. In 
addition, the significant presence of iron in all the samples studied and its eventual contribution to the formation of scission products by photo-oxidation requires further attention.

- The changing mechanical properties of oil paint films. The fact of using samples that were casted in the 1980s and 1990s and already tested and analyzed in the early years of their drying process also contributed to monitor the changes induced in time in the chemical composition and the mechanical properties of the selected paint films as a function of the pigments and medium present in their composition.

- The role of additives in the mechanical properties of the selected paint films. The fact that Grumbacher ${ }^{\circledR}$ paint films are somehow stiffer and stronger than the Gamblin ${ }^{\circledR}$ ones suggest that additives do influence paint film's performance. This is an interesting stimulus for further investigation of the exact role additives play in the behaviour of commercial paint films to understand to which extent they can enhance the changes observed in the mechanical properties of the different commercial paint films.

-The changes induced by degradation phenomena such as hydrolysis, that lead to weak and soft films in the case of earthy paints;

Finally, this research has shown how complex the chemical characterization of modern oils is as well as the complexity behind the failure mechanisms observed in the selected paint films. As far as it can be deducted from the results, for a same given colour completely different behaviours and alterations can be expected in modern paintings as a result of the chemical and mechanical interactions of pigments and medium, and where the environment not necessarily has to play any role for degradation. There are still some issues left to understand regarding the exact interactions taking place between the organic and inorganic fractions of the different paint films and that will probably be dependent on the type and amount of additives present in each commercial formulation. Understanding such interactions will be crucial to design the proper conservation strategies when treating paintings but also when recommending environmental guidelines for our collections.

\section{ACKNOWLEDGEMENTS}

The authors are deeply indebted to Dr. M.F. Mecklenburg (Museum Conservation InstituteSmithsonian Institution, USA) for providing the samples tested in this study and for the equipment donated. Gamblin Artists Colors and Kremer Pigmente GmbH \& Co. KG are equally acknowledged for assisting with technical information regarding the materials tested. The authors also want to thank M. Planes and Dr. Moya (Microscopy Service, UPV) as well as Dra. Mestre (XRD Service at S.C.S.I.E, Universidad de Valencia-UV) for their technical assistance. This research was also possible thanks to the financial support from Ca' Foscari University of Venice (IRIDE departmental fund) and UPV Progr ama de Incentivo a la Investigación (PAID-UPV-06-10-2429). 


\section{REFERENCES}

[1] A. Burnstock, K.J. Van den Berg, S. De Groot, L. Wijnberg, An investigation of water-sensitive oil paints in twentieth century paintings, in: J.S. Learner, P. Smithen, J.W. Krueger, M.R. Schilling (Eds.), Modern Paints Uncovered, Proceedings from the Modern Paints Uncovered Symposium, The Getty Conservation Institute, Los Angeles, 2006, pp. 177-188.

[2] L. Mills, A. Burnstock, F. Duarte et al., Water sensitivity of modern artists' oil paint, in: ICOM Committee for Conservation, vol. 2, Allied publishers, India, 2008, pp. 651-659.

[3] Tempest, A. Burnstock, P. Saltmarsh, K.J. Van den Berg, Sensitivity of Oil Paint Surfaces to Aqueous and Other Solvents, in: M.F. Mecklenburg, A.E. Charola, R.J. Koestler (Eds.), in: New Insights into the Cleaning of Paintings, Proceedings from the Cleaning 2010 International Conference, Universidad Politécnica de Valencia and Museum Conservation Institute, Smithsonian Institution Scholarly Press, Washington, 2013, pp. 107-114.

[4] Silvester, A. Burnstock, L. Megens L., T. Learner, G. Chiari, K. J. van den Berg, A cause of watersensitivity in modern oil paint films: the formation of magnesium sulphate, Studies in Conservation, 59:1 (2014) 38-51.

[5] J.D.J. Van den Berg, A. Burnstock, Twentieth Century Oil Paint. The interface between Science and Conservation and the Challenges for modern oil paint research in: $\mathrm{K}$. J. van den Berg, $A$. Burnstock, M. de Keijzer Matthijs, J. Krueger, T. Learner, A. de Tagle, G.Heydenreich (Ed), Issues in Contemporary Oil paints, Springer International Publishing, The Netherlands, 2014, pp.1-20.

[6] F.C. Izzo, B. Ferriani, K. J. van den Berg, H. van Keulen, E. Zendri, 20th century artists' oil paints: The case of the Olii by Lucio Fontana, Journal of Cultural Heritage, 15 (2014) 557-563.

[7] F.C. Izzo, K.J. van den Berg, H. van Keulen, E. Zendri, B. Ferriani, Modern Oil Paints Formulations, organic additives and degradation: some case studies, in K. J. van den Berg, A. Burnstock, M. de Keijzer Matthijs, J. Krueger, T. Learner, A. de Tagle, G.Heydenreich (Ed), Issues in Contemporary Oil paints, Springer International Publishing, The Netherlands, 2014, pp.75-104.

[8] K. Helwig, A note on burnt yellow earth pigments: documentary sources and scientific analysis, Studies in Conservation, 42 (1997) 181-188.

[9] T. Hradil, J. Grygar, P. Hradilova', P. Bezdicka, Clay and iron oxide pigments in the history of painting, Applied Clay Science, 22 (2003) 223-236.

[10] C. Genestar, C. Pons, Earth pigments in painting: characterization and differentiation by means of FTIR spectroscopy and SEM-EDS microanalysis, Analytical and bioanalytical chemistry, 382 (2005) 269-274. 
[11] K. Helwig, Iron Oxide Pigments. Natural and Synthetic, in: B.H. Berrie (Ed.), Artists' Pigments: A Handbook of their History and Characteristics, Vol. 4, National Gallery of Art, Washington, in association with Archetype Publications Ltd., London, 2007, pp. 39-110.

[12] R.J. Meilunas, J.G. Bentsen, A. Steinberg, Analysis of aged paint binders by FTIR spectroscopy, Studies in Conservation, 35 (1990) 33-51.

[13] Rasti, G. Scott, The effects of some common pigments on the photo-oxidation of linseed oilbased paint media, Studies in Conservation, 25 (1980) 145-156.

[14] M.F. Mecklenburg, C.S. Tumosa, D. Erhardt, The changing mechanical properties of aging oil paints, in: P.B. Vandiver, J.L. Mass, A. Murray (Eds.), Materials Issues in Art and Archaeology, VII, 852 (2004), Materials Research Society, pp. 13-24.

[15] M.F. Mecklenburg, C.S. Tumosa, Mechanical Behavior of Paintings Subjected to Changes in Temperature and Relative Humidity, in: M.F. Mecklenburg (Ed.), Art in Transit: Studies in the Transport of Paintings, National Gallery of Art, Washington, 1991, pp. 173-216.

[16] M.F. Mecklenburg, Some Aspects of the Mechanical Behavior of Fabric Supported Paintings, Report submitted to the Smithsonian Institution under the National Museum Act, Washington D.C., 1982.

[17] M.F. Mecklenburg, C.S. Tumosa, E.P. Vicenzi, The influence of pigments and ion migration on the durability of drying oil and alkyd paints, in: M.F. Mecklenburg, A.E. Charola, R.J. Koestler (Eds.), New Insights into the Cleaning of Paintings, Proceedings from the Cleaning 2010 International Conference, Universidad Politécnica de Valencia and Museum Conservation Institute, Smithsonian Institution Scholarly Press, Washington, 2013, pp. 59-67.

[18] Z.W. Wicks, Drying Oils, in: H.F. Mark, N.M. Bikales, C.G. Overberger, G. Menges (Eds.), Encyclopedia of polymer science and engineering, second ed., Vol. 5, John Wiley \& Sons, Inc., New York, 1986, pp. 203-214.

[19] R. Mayer, The artist's handbook of materials and techniques, fifth ed., Revised and updated by Steven Sheehan (Ed.), Viking Press, New York, 1991.

[20] J.D.J. Van den Berg, Analytical chemical studies on traditional linseed oil paints, PhD thesis, University of Amsterdam, MOLART Reports (6), AMOLF, Amsterdam, 2002.

[21] C.S. Tumosa, M.F. Mecklenburg, The influence of lead ions on the drying of oils, Reviews in Conservation, 6 (2005) 43-51.

[22] C.S. Tumosa, M.F. Mecklenburg, Oil Paints: The Chemistry of Drying Oils and the Potential for Solvent Disruption, in: M.F. Mecklenburg, A.E. Charola, R.J. Koestler (Eds.), New Insights into the Cleaning of Paintings, Proceedings from the Cleaning 2010 International Conference, Universidad Politécnica de Valencia and Museum Conservation Institute, Smithsonian Institution Scholarly Press, Washington, 2013, pp. 51-58. 
[23] S. Mansour, Use of ZAF and PAP matrix correction models for the determination of carbon in steels by electron probe microanalysis, X-Ray Spectrometry, Vol. 18, Issue 6 (1989) 263-266.

[24] L. Osete-Cortina, M.T. Doménech-Carbó, A. Doménech, D.J. Yusá-Marco, H. Ahmadi, Multimethod analysis of Iranian Ilkhanate ceramics from the Takht-e Soleyman palace, Analitical and Bioanalytical Chemistry, 397 (2010) 319-329.

[25] K. R. Sutherland, Derivatisation using m-(trifluoromthyl)phenyltrimethylammonium hydroxide of organic materials in artworks for analysis by gas chromatography-mass spectrometry: Unusual reaction products with alcohols, in Journal of chromatography A, vol. 1149 (2007) 30-37.

[26] F.C. Izzo, 20th century artists' oil paints: a chemical-physical survey, PhD thesis, University "Ca' Foscari", Venice, 2011.

[27] M.F. Mecklenburg, C.S. Tumosa, An Introduction into the Mechanical Behavior of Paintings under Rapid Loading Conditions, in: M.F. Mecklenburg (Ed.), Art in Transit: Studies in the Transport of Paintings, National Gallery of Art, Washington, 1991, pp. 137-171.

[28] S. Croll, Overview of developments in the paint industry since 1930, in: J.S. Learner, P. Smithen, J.W. Krueger, M.R. Schilling (Eds.), Modern Paints Uncovered, Proceedings from the Modern Paints Uncovered Symposium, The Getty Conservation Institute, Los Angeles, 2007, pp. 17-29.

[29] T.J.S. Learner, Analysis of Modern Paints, Research in Conservation, The Getty Conservation Instituite, Los Angeles, 2004.

[30] R. Ploeger, D. Scalarone, O. Chiantore, Thermal analytical study of the oxidative stability of artists' alkyd paints, Polymer Degradation and Stability, 94 (2009) 2036-2041.

[31] C. Duce, L. Bernazzani, E. Bramanti, A. Sepi, M.P. Colombini, M.R. Tiné, Alkyd artists' paints: Do pigments affect the stability of the resin? A TG and DSC study on fast-drying oil colours, Polymer Degradation and Stability, 105 (2014) 48-58.

[32] J.S. Mills, The gas chromatographic examination of paint media. Part I. Fatty acid composition and identification of dried oil film, Studies in Conservation, 11 (1966) 92-108.

[33] Colombini M. P., Modugno F., Organic mass spectrometry in art and archaeology, Wiley \& Sons, New York,2009.

[34] J. La Nasa, E. Ghelardi, I. Degano, F. Modugno, M.P. Colombini, Core shell stationary phases for a novel separation of triglycerides in plant oils by high performance liquid chromatography with electrospray-quadrupole-time of flight mass spectrometer, Journal of Chromatography A, Vol 1308 (2013) 114-124.

[35] V. Dubois, S. Breton, M. Linder, J. Fanni, M. Parmentier, Fatty acid profiles of 80 vegetable oils with regard to their nutritional potential, European Journal of Lipid Science and Technology, Vol 109, Issue 7 (2007) 710-732. 
[36]C.S. Tumosa, A Brief History of Aluminum Stearate as a Component of Paint, Western Association for Art Conservation (WAAC) Newsletter, vol. 23, no. 3 (2001) 10-11.

[37] D. Erhardt, Paints based on drying oil media, in: V. Dorge, F.C. Howlett (Eds.), Painted wood: History and conservation, The Getty Conservation Institute, Los Angeles, 1998, pp. 17-32.

[38] M. R. Schilling, H. P. Khanjian, D. M. Carson, Fatty acid and glycerol content of lipids; effect of ageing and solvent extraction on the composition of oil paints, in Techne, vol. 5 (1997) 71-78.

[39] R. Mazzeo, S. Prati, M. Quaranta, E. Joseph, E. Kendix, M. Galeotti, Attenuated total reflection micro FTIR characterisation of pigment-binder interaction in reconstructed paint films, Analytical and Bioanalytical Chemistry, 392 (2008) 65-76.

[40] R. J. Gettens, G.L. Stout, Painting Materials: A Short Encyclopedia, Dover Pubblications, New York, 1966.

[41] C.S. Tumosa, D. Erhardt, M.F. Mecklenburg, X. Su, Linseed oil paint as ionomer: synthesis and characterization, Materials Issues in Art and Archaeology VII, 852 (2005), Materials Research Society, pp. 25-31. 

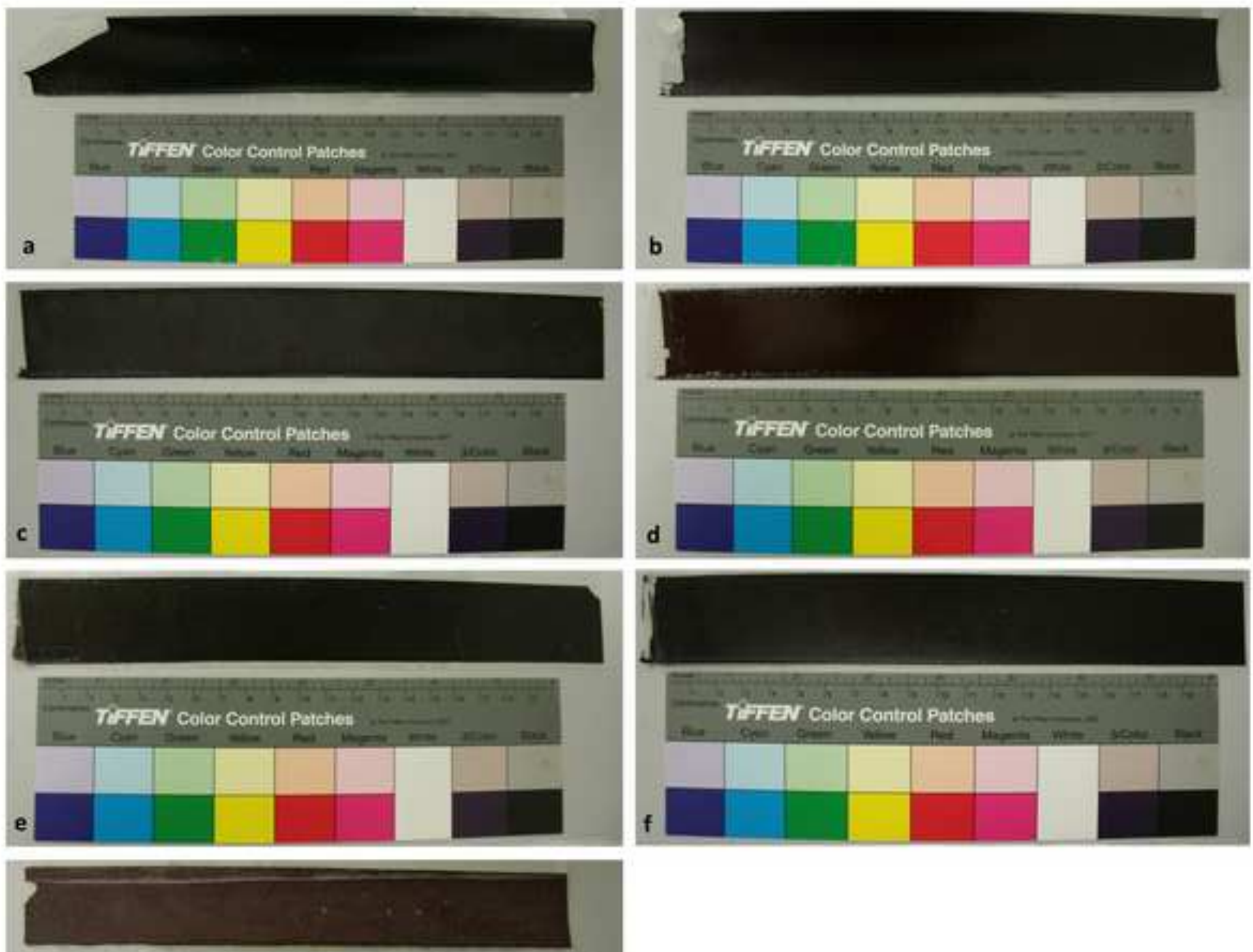

THFEN Color Control Patches

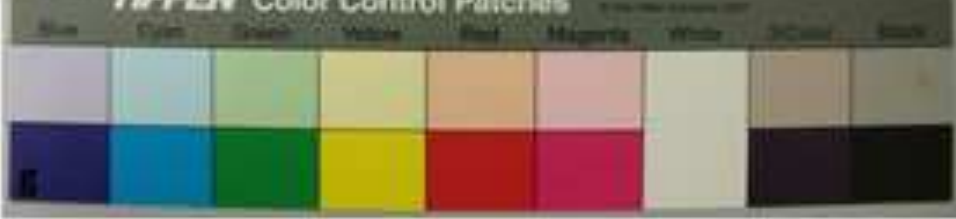




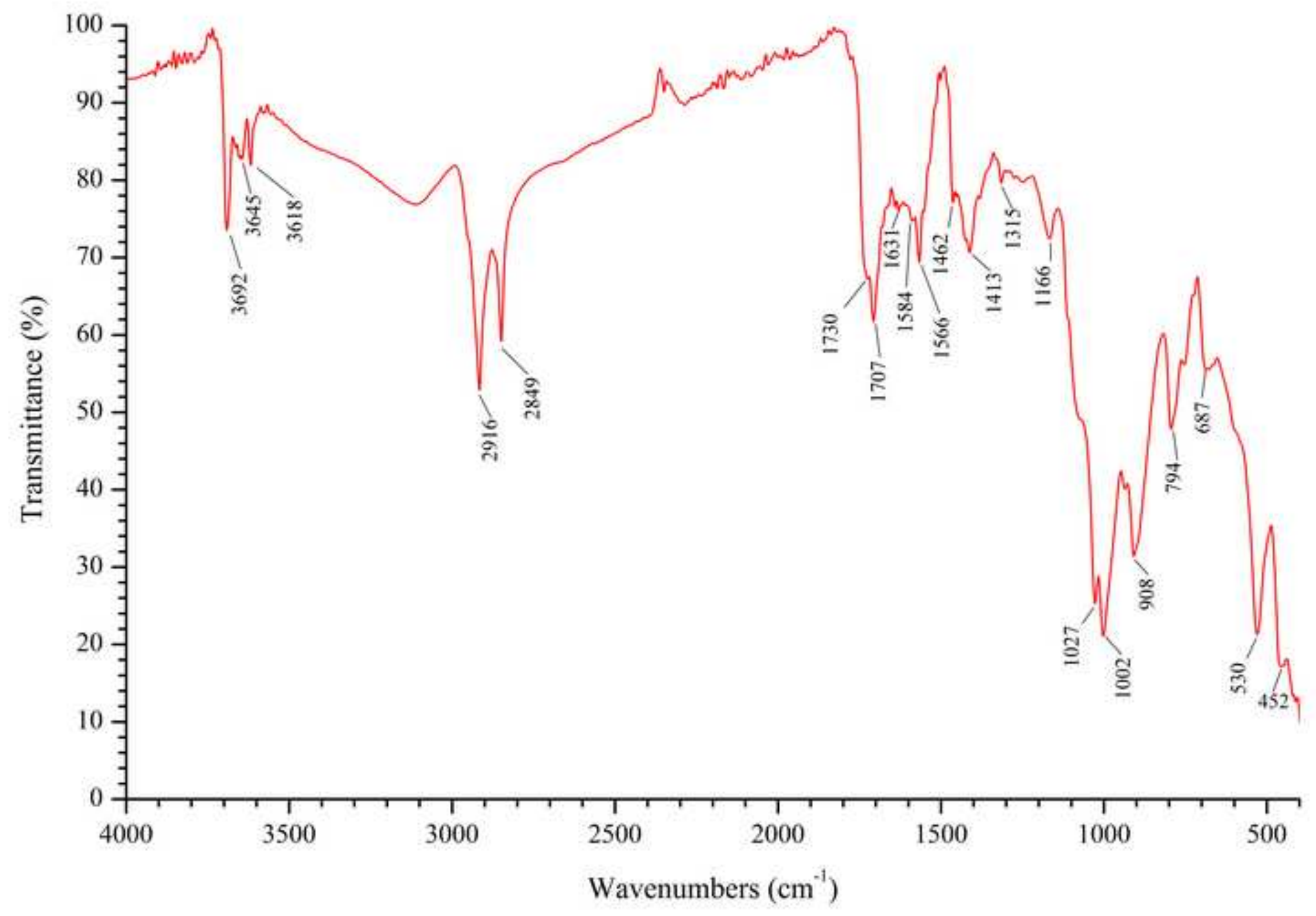




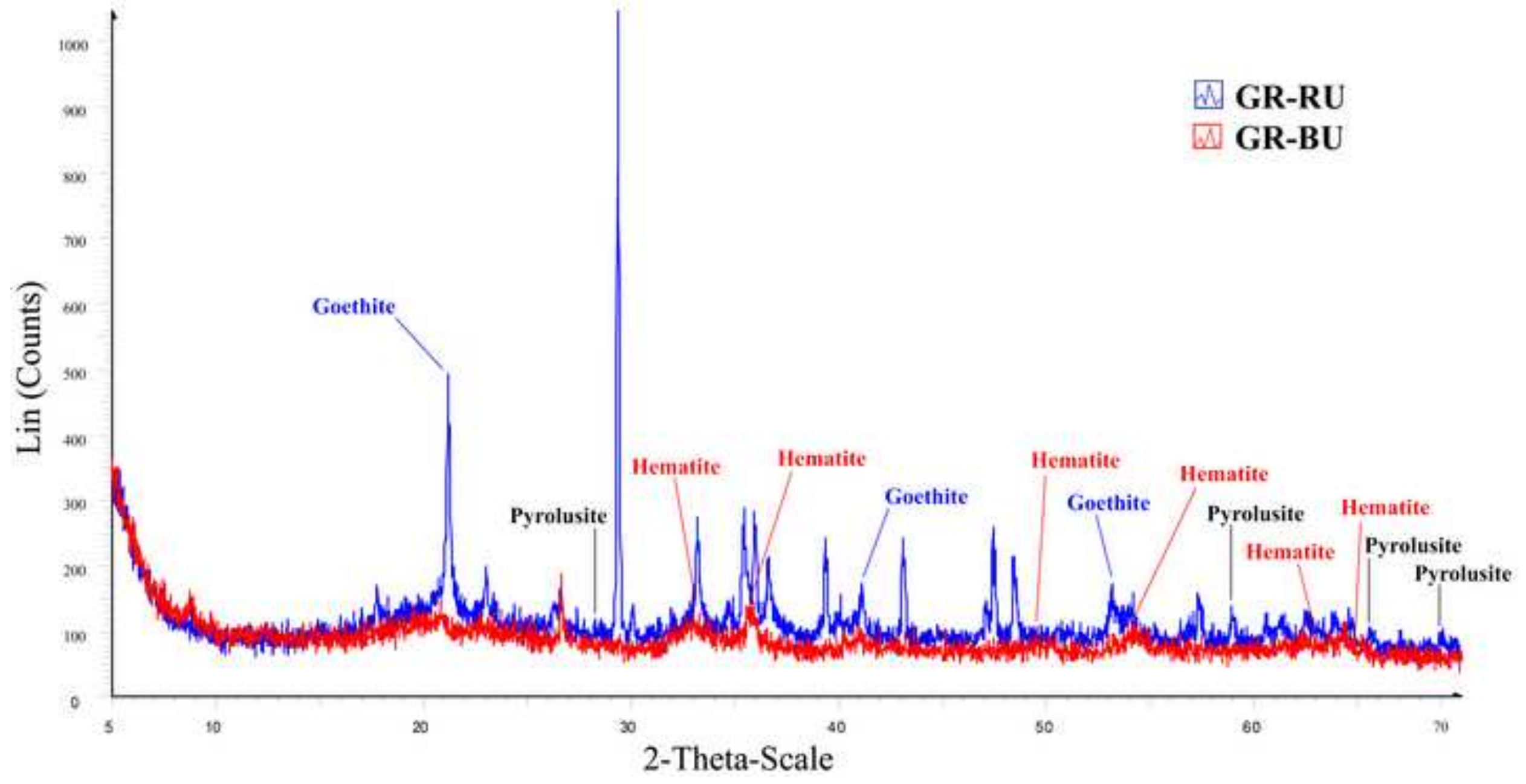



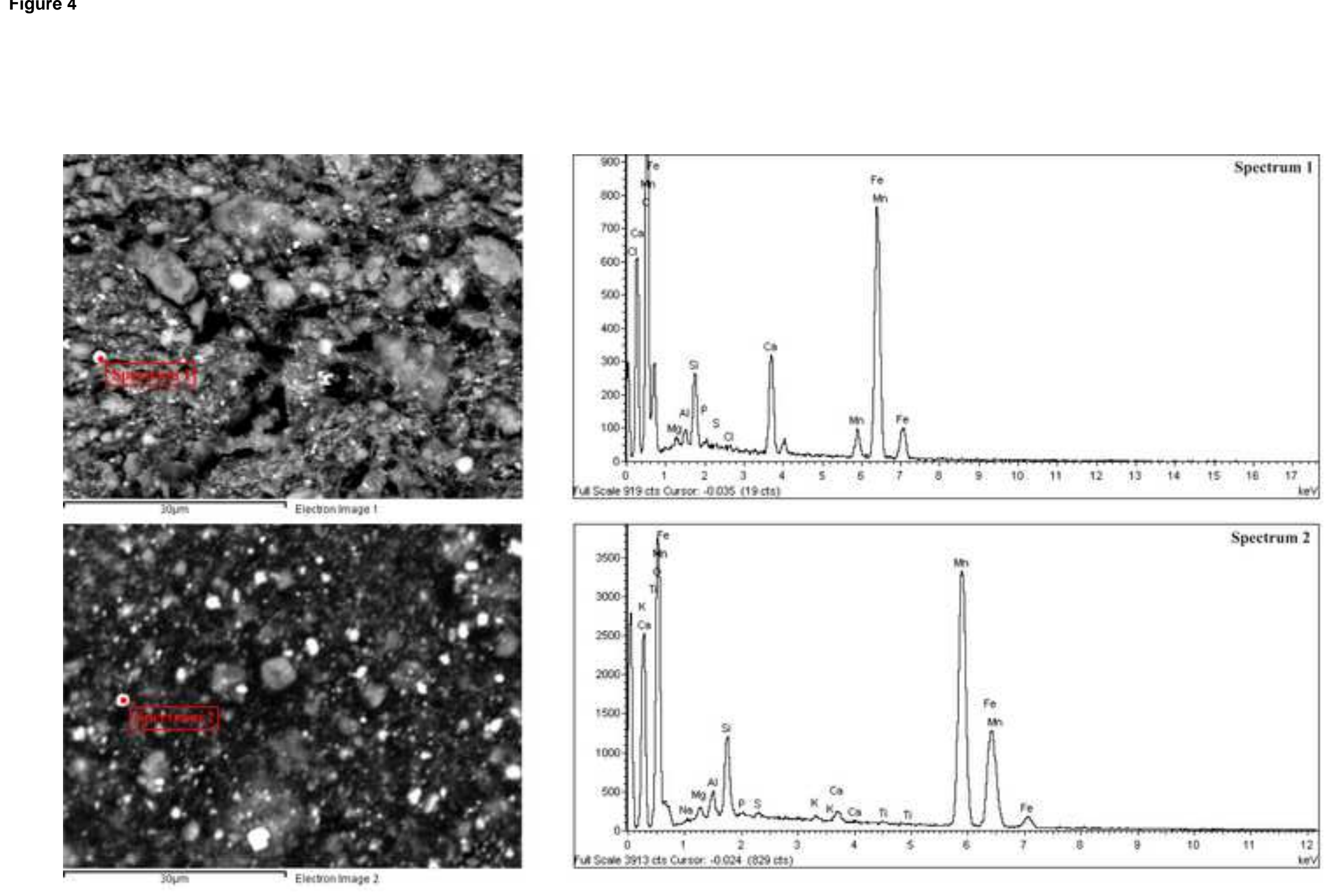

$$
\text { 30p } 2 \text { Electron image } 2
$$

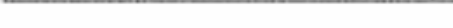

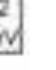




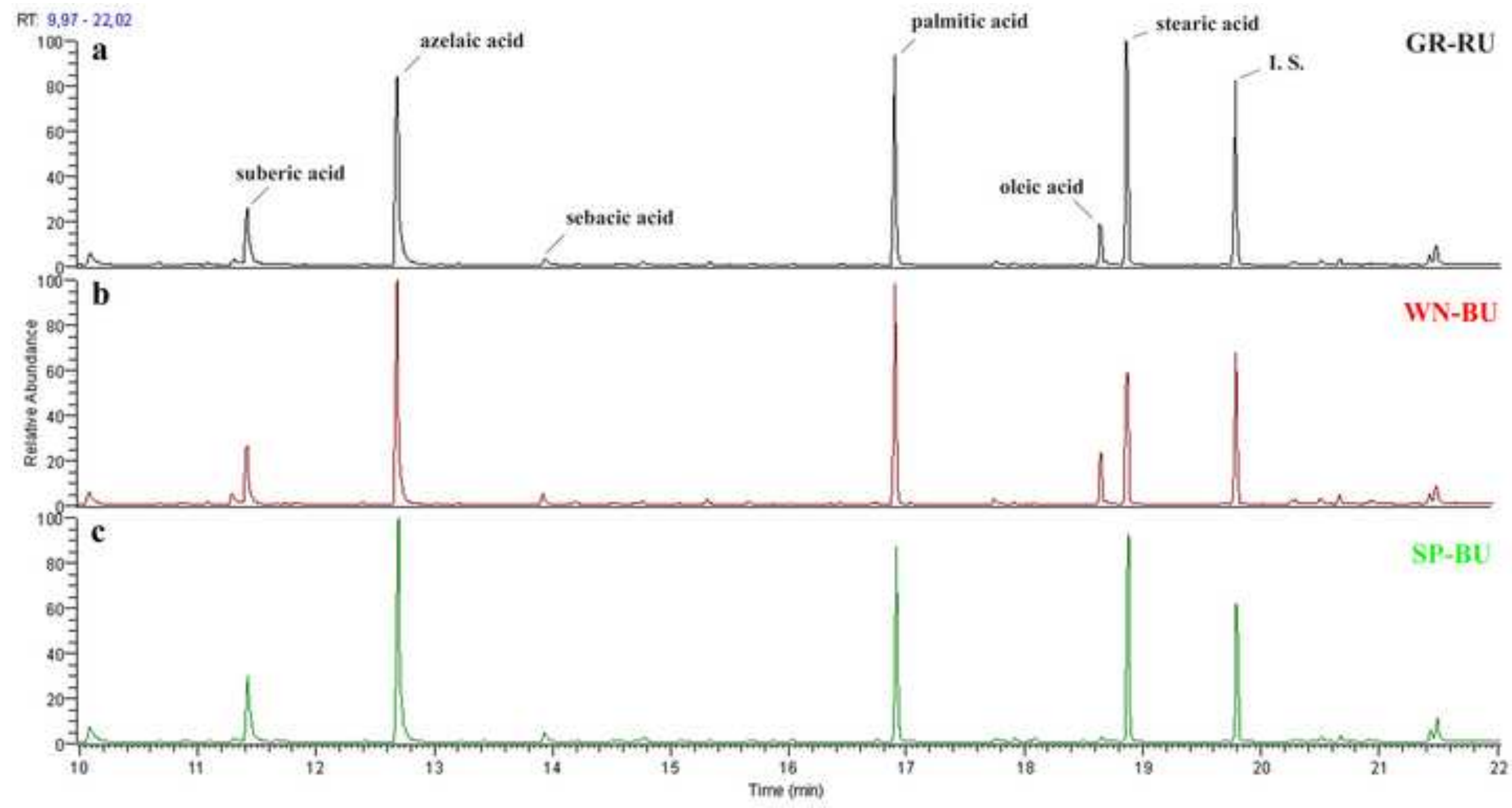




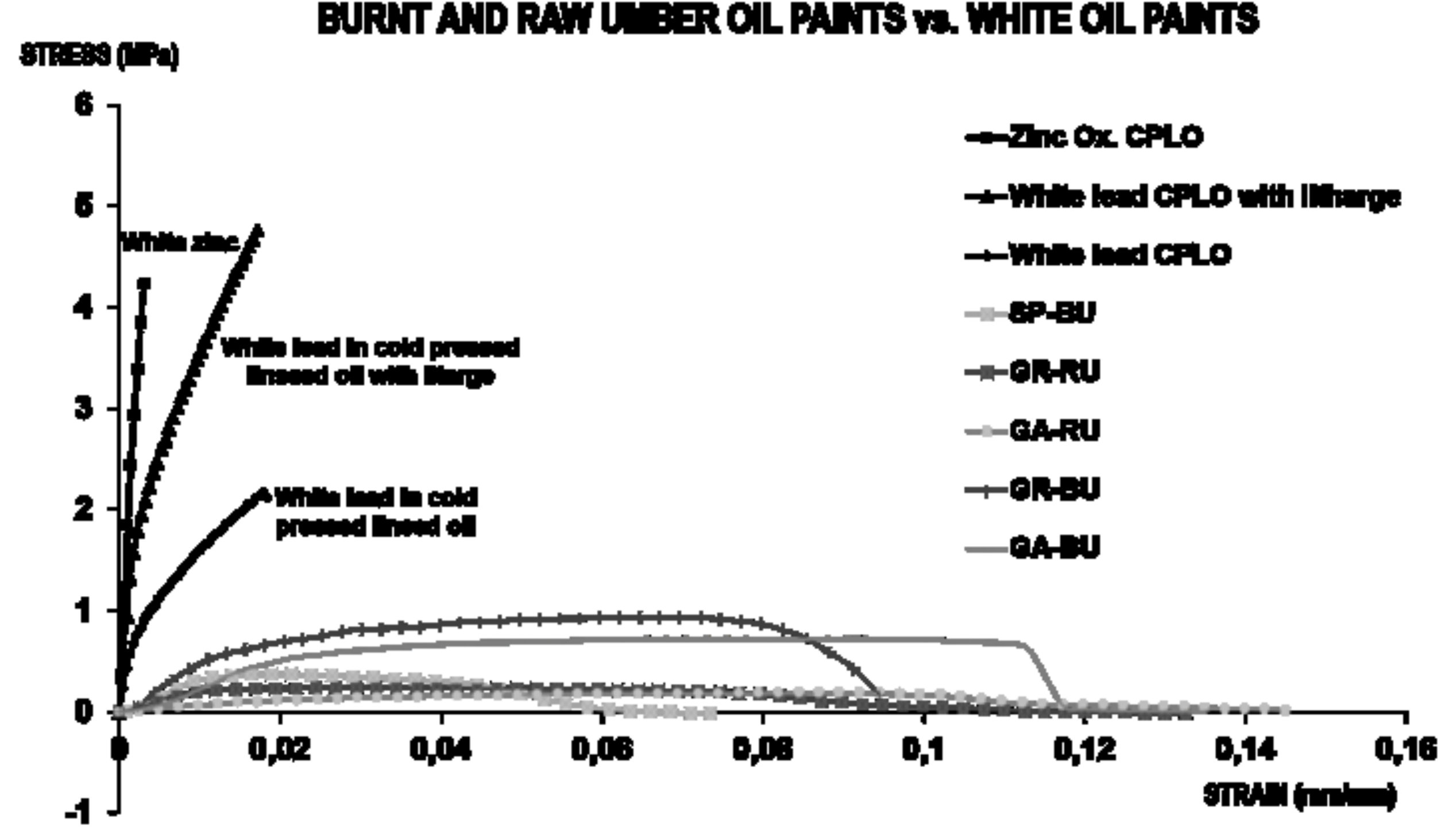




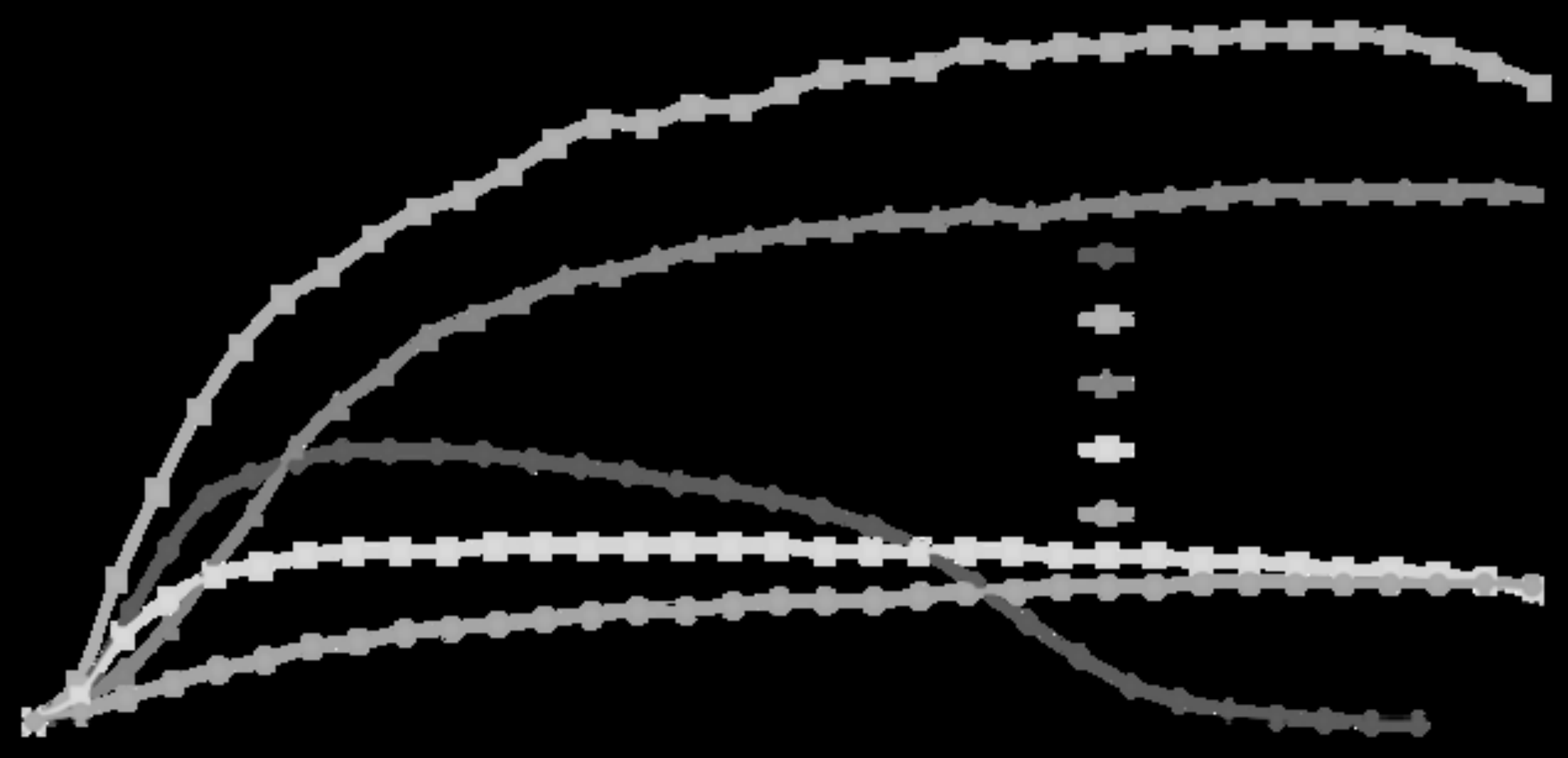




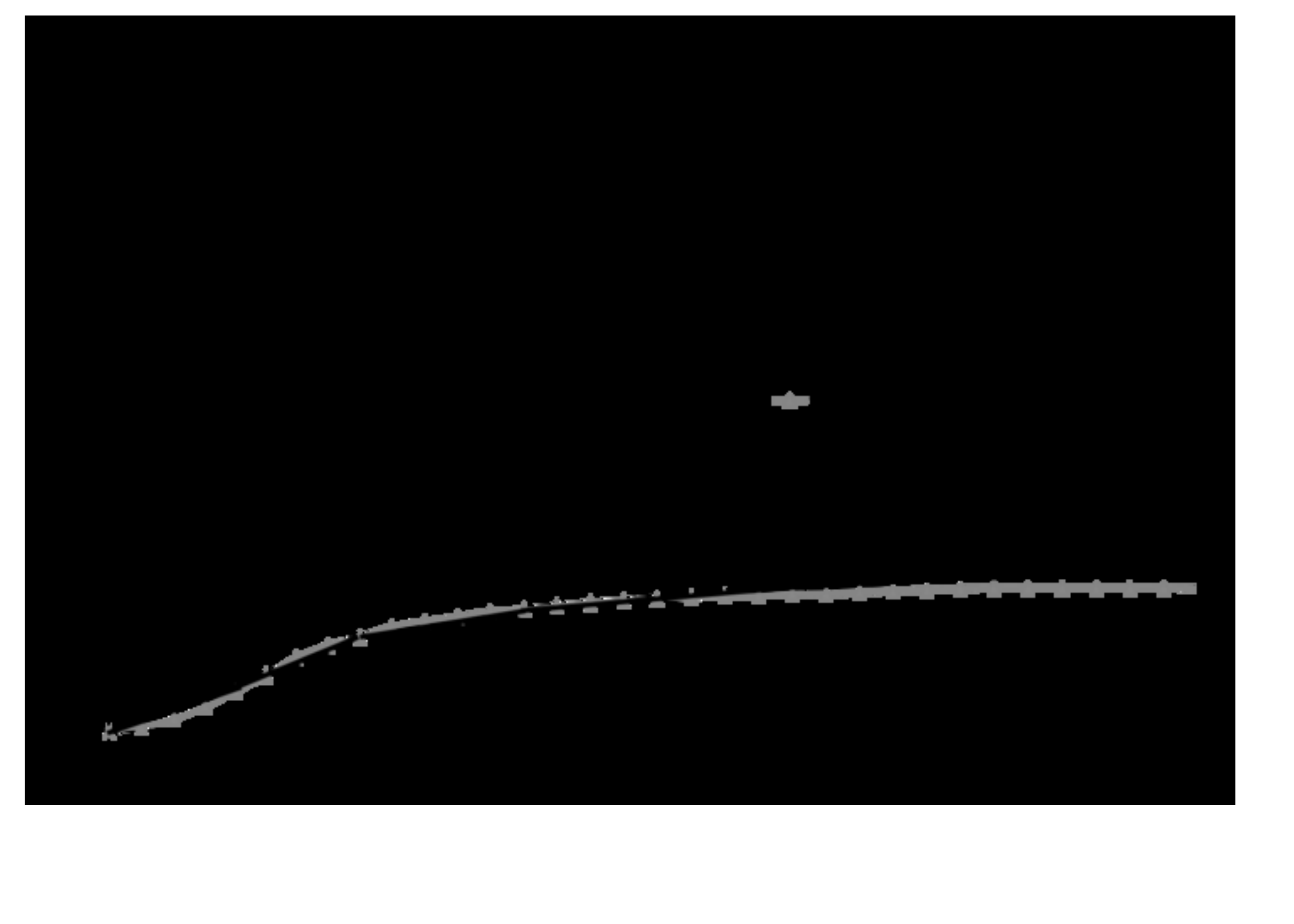

9

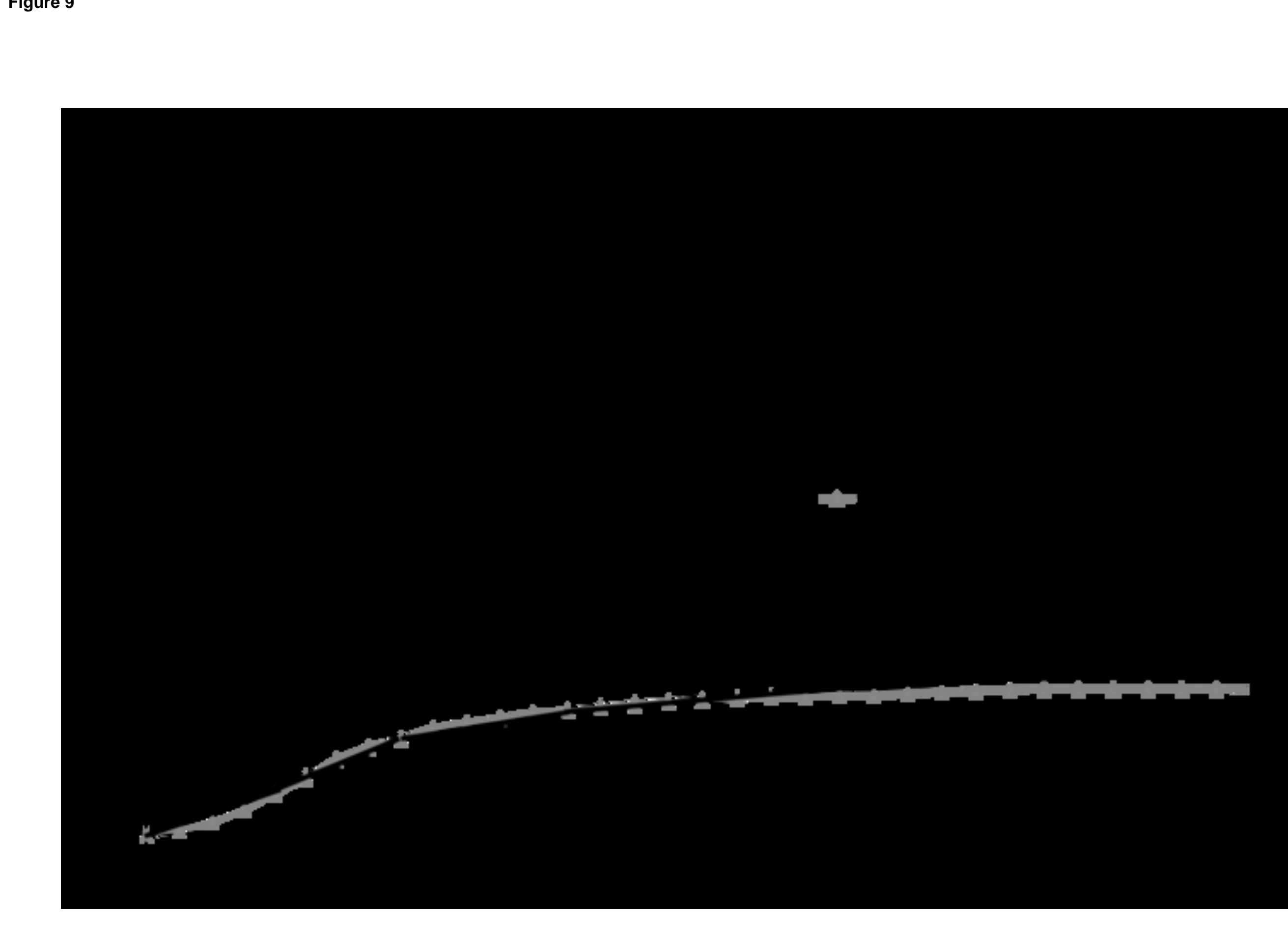




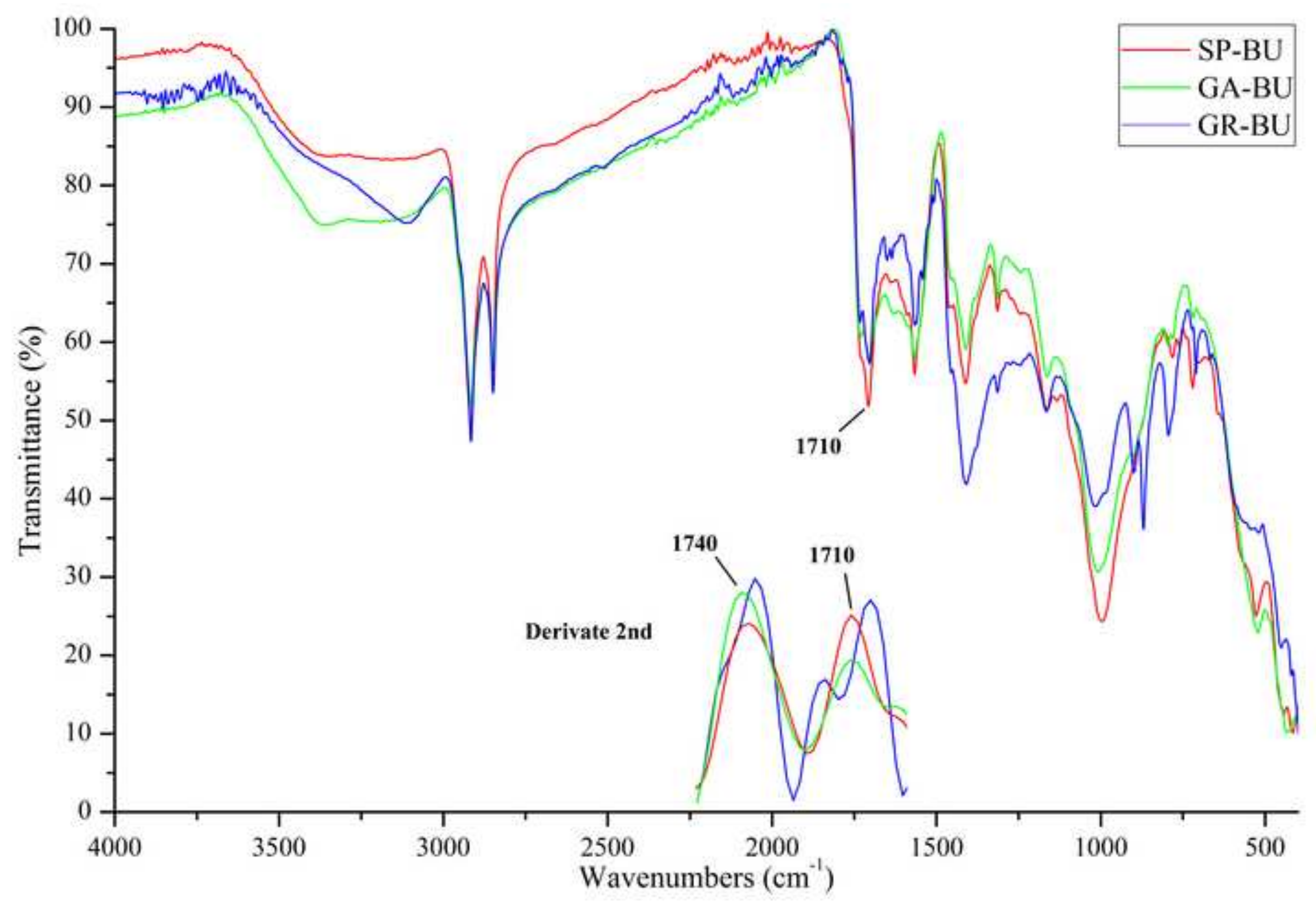




\section{Caption for figures}

Figure 1 - The commercial paint films selected for this study: a) WN-RU, b) WN-BU, c) GA-RU, d) GA-BU, e) GR-RU, f) GR-BU, g) SP-BU.

Figure 2 - FT-IR-ATR spectrum of GA-RU. The peaks in the region between 3700 and $3600 \mathrm{~cm}^{-1}$ are typical of stratified silicates.

Figure 3 - comparison of GR-RU and GR-BU diffractograms. The comparison shows the presence of goethite in the raw umber, hematite in burnt umber, and pyrolusite in both types of pigments.

Figure 4 - (above) GR-RU: SEM image of the section of the sample obtained by EBSD (2000X) (a), EDX of a grain of pigment identified as iron oxide (b). (under) GR-BU: SEM image of the section of the sample obtained by EBSD (2000X) (a), EDX of a grain of pigment identified as manganese oxide (b).

Figure 5 - Total ion current chromatograms of Grumbacher ${ }^{\circledR}$ raw umber (a), Winsor \& Newton ${ }^{\circledR}$ burnt umber (b) and Speedball ${ }^{\circledast}$ burnt umber (c).

Figure 6 - Stress versus strain plots of commercial raw and burnt umbers in comparison with films pigmented with lead and zinc white.

Figure 7 - Stress versus strain plots of different commercial raw and burnt umbers.

Figure 8 - Stress versus strain plots of Grumbacher $^{\circledR}$ burnt umbers in different drying stages and with different manganese content.

Figure 9 - Stress versus strain plots of Gamblin ${ }^{\circledR}$ burnt umbers in different drying stages and with different manganese content.

Figure 10 - FTIR-ATR spectra of Gamblin ${ }^{\circledR}$, Grumbacher $^{\circledR}$ and Speedball ${ }^{\circledR}$ burnt umber oil paint films. 
Table 1a - Paint samples studied (from Mecklenburg's Paint Reference Collection)

\begin{tabular}{|c|c|c|c|c|c|c|}
\hline \multicolumn{2}{|c|}{ Sample* } & \multicolumn{2}{|c|}{ Manufacturers' description** } & \multirow{2}{*}{$\begin{array}{l}\text { Thickness } \\
0.23 \mathrm{~mm}\end{array}$} & \multirow{2}{*}{$\begin{array}{l}\text { Casting Date } \\
18 / 03 / 1999\end{array}$} & Tensile tests run in: \\
\hline \multirow{3}{*}{ Raw Umbers } & WN-RU & $\begin{array}{l}\text { WINSOR \& NEWTON }{ }^{\circledR} \\
\text { Artists Oil Colours }\end{array}$ & $\begin{array}{c}\text { Raw umber, } 554, \text { Permanence AA, Series } \\
1, \text { Natural iron oxide (PBr7), LSO*** }\end{array}$ & & & \multirow{7}{*}{2003 (Mecklenburg et al. 2013) [17] } \\
\hline & GA-RU & $\begin{array}{c}\text { GAMBLIN }^{\circledR} \\
\text { Artists Oil Colors }\end{array}$ & $\begin{array}{c}\text { Raw umber, Natural iron oxide } \\
\text { containing manganese (PBr7), ARLO*** }\end{array}$ & $0.23 \mathrm{~mm}$ & 22/03/1999 & \\
\hline & GR-RU & $\begin{array}{c}\text { GRUMBACHER }{ }^{\circledR} \\
\text { Pretested Artists Oil Colors }\end{array}$ & $\begin{array}{c}\text { Raw umber, } \mathrm{P} 172, \text { Natural iron oxide } \\
\text { containing manganese (PBr7), Black iron } \\
\text { oxide (PBk1), ARLO*** }\end{array}$ & $0.22 \mathrm{~mm}$ & 19/03/1999 & \\
\hline \multirow{4}{*}{ Burnt Umbers } & WN-BU & $\begin{array}{l}\text { WINSOR \& NEWTON }{ }^{\circledR} \\
\text { Artists Oil Colours }\end{array}$ & $\begin{array}{l}\text { Burnt umber, 076, Permanence AA, } \\
\text { Series 1, Calcined natural iron oxide } \\
\text { (PBr7), LSO*** }\end{array}$ & $0.23 \mathrm{~mm}$ & 18/03/1999 & \\
\hline & GA-BU & $\begin{array}{l}\text { GAMBLIN }^{\circledR} \\
\text { Artists Oil Colors }\end{array}$ & $\begin{array}{l}\text { Burnt umber, Calcined natural iron oxide } \\
\text { containing manganese ( } \mathrm{PBr} 7), \mathrm{ARLO}^{* * *}\end{array}$ & $0.25 \mathrm{~mm}$ & 22/03/1999 & \\
\hline & GR-BU & $\begin{array}{l}\text { GRUMBACHER }{ }^{\circledR} \\
\text { Pretested Artists Oil Colors }\end{array}$ & $\begin{array}{l}\text { Burnt umber, P024, Calcined natural iron } \\
\text { oxide containing manganese (PBr7), } \\
\text { ARLO*** }\end{array}$ & $0.27 \mathrm{~mm}$ & 19/03/1999 & \\
\hline & SP-BU & SPEEDBALL ${ }^{\circledR}$ & $\begin{array}{l}\text { Burnt umber, } \# 5602 \text {, Calcined iron oxide, } \\
\text { LO*** }\end{array}$ & $0.32 \mathrm{~mm}$ & 21/02/1981 & \\
\hline
\end{tabular}

* RU = Raw umber; BU = Burnt umber; WN = Winsor \& Newton; GA = Gamblin; GR = Grumbacher

** based on manufacturers' datasheets available in the 1980-1990's

$* * *$ LSO = Linseed/Safflower oils; ARLO = Alkali refined linseed oil; LO = Linseed oil 
Table 1b- White test paints made from pigments mixed in cold pressed linseed oil (from Mecklenburg's Paint Reference Collection)

\begin{tabular}{|c|c|c|c|c|c|c|c|}
\hline Paint Sample & $\begin{array}{c}\text { Pigment Volume } \\
\text { Concentration } \\
(\%)\end{array}$ & $\begin{array}{c}\text { Oil Volume } \\
\text { Concentration(\%) }\end{array}$ & Pigment Weight (\%) & Oil Weight (\%) & Thickness & Casting Date & Tensile tests run in: \\
\hline Lead White in CPLO* & 44.4 & 55.6 & 84.1 & 15.9 & $0.26 \mathrm{~mm}$ & 1999 & \multirow{2}{*}{$\begin{array}{c}2003 \text { (Mecklenburg et al. } \\
\text { 2004) [19] }\end{array}$} \\
\hline Zinc White in CPLO* & 35.1 & 64.9 & 75.1 & 24.9 & $0.26 \mathrm{~mm}$ & 1999 & \\
\hline
\end{tabular}

*CPLO $=$ cold pressed linseed oil 
Table2 - Resume of the results of the chemical characterisation

\begin{tabular}{|c|c|c|c|}
\hline & \multirow{2}{*}{ Sample } & \multicolumn{2}{|c|}{ Chemical composition } \\
\hline & & Inorganic Fraction* & Organic Fraction** \\
\hline \multirow{3}{*}{$\begin{array}{l}\text { Raw } \\
\text { Umbers }\end{array}$} & $\begin{array}{l}\text { WN- } \\
\text { RU }\end{array}$ & $\begin{array}{l}\text { Goethite }[\alpha-\mathrm{FeO}(\mathrm{OH})] \text {, manganese oxides, magnesium silicate }\left(\mathrm{Mg}_{2} \mathrm{SiO}_{4}\right) \text {, calcite } \\
\left(\mathrm{CaCO}_{3}\right) \text {, dolomite }\left[\mathrm{CaMg}\left(\mathrm{CO}_{3}\right)_{2}\right] \text {, calcium phosphate }\left[\mathrm{Ca}_{3}\left(\mathrm{PO}_{4}\right)_{2}\right]\end{array}$ & $\begin{array}{l}\text { Drying oil: } \mathrm{P} / \mathrm{S}=1.3, \mathrm{~A} / \mathrm{P}=1.7, \mathrm{O} / \mathrm{S}=0.2 \\
\text { Metal soaps (probably manganese carboxylates or added stearates as dispersing agents) }\end{array}$ \\
\hline & GA-RU & $\begin{array}{l}\text { Goethite }[\alpha-\mathrm{FeO}(\mathrm{OH})] \text {, iron oxide }(\mathrm{III})\left(\mathrm{Fe}_{2} \mathrm{O}_{3}\right) \text {, pyrolusite }\left(\mathrm{MnO}_{2}\right) \text {, kaolinite } \\
\left(\mathrm{Al}_{2} \mathrm{Si}_{2} \mathrm{O}_{5}(\mathrm{OH})_{4}\right) \text {, illite }\left(\mathrm{K}, \mathrm{H}_{3} \mathrm{O}\right)(\mathrm{Al}, \mathrm{Mg}, \mathrm{Fe})_{2}\left(\mathrm{Si}_{1} \mathrm{Al}\right)_{4} \mathrm{O}_{10}\left[(\mathrm{OH})_{2},\left(\mathrm{H}_{2} \mathrm{O}\right)\right] \text {, potassium magnesium } \\
\text { silicate }\left[\mathrm{K}_{2}\left(\mathrm{MgSi}_{5} \mathrm{O}_{12}\right)\right] \text {, calcium carbonate }\left(\mathrm{CaCO}_{3}\right)\end{array}$ & $\begin{array}{l}\text { Drying oil: } \mathrm{P} / \mathrm{S}=2.1, \mathrm{~A} / \mathrm{P}=1.1, \mathrm{O} / \mathrm{S}=0.1 \\
\text { Metal soaps (probably manganese carboxylates or added stearates as dispersing agents) }\end{array}$ \\
\hline & GR-RU & $\begin{array}{l}\text { Goethite }[\alpha-\mathrm{FeO}(\mathrm{OH})] \text {, iron oxide }(\mathrm{IIII})\left(\mathrm{Fe}_{2} \mathrm{O}_{3}\right) \text {, pyrolusite }\left(\mathrm{MnO}_{2}\right) \text {, magnesium silicate, } \\
\text { sodium aluminium silicate, calcite }\left(\mathrm{CaCO}_{3}\right) \text {, calcium phosphate }\left[\mathrm{Ca}_{3}\left(\mathrm{PO}_{4}\right)_{2}\right]\end{array}$ & $\begin{array}{l}\text { Drying oil: } \mathrm{P} / \mathrm{S}=0.9, \mathrm{~A} / \mathrm{P}=1.8, \mathrm{O} / \mathrm{S}=0.2 \\
\text { Metal soaps (probably manganese carboxylates or added stearates as dispersing agents) }\end{array}$ \\
\hline \multirow{4}{*}{$\begin{array}{l}\text { Burnt } \\
\text { Umbers }\end{array}$} & $\begin{array}{l}\text { WN- } \\
\text { BU }\end{array}$ & $\begin{array}{l}\text { Hematite }\left(\alpha-\mathrm{Fe}_{2} \mathrm{O}_{3}\right) \text {, pyrolusite }\left(\mathrm{MnO}_{2}\right) \text {, manganese oxide }\left(\mathrm{Mn}_{3} \mathrm{O}_{4}\right) \text {, quartz }\left(\alpha-\mathrm{SiO}_{2}\right) \text {, } \\
\text { spinel }\left(\mathrm{MgAl}_{2} \mathrm{O}_{4}\right) \text {, dolomite }\left[\mathrm{CaMg}\left(\mathrm{CO}_{3}\right)_{2}\right] \text {, calcite }\left(\mathrm{CaCO}_{3}\right)\end{array}$ & $\begin{array}{l}\text { Drying oil: } \mathrm{P} / \mathrm{S}=1.6, \mathrm{~A} / \mathrm{P}=1.7, \mathrm{O} / \mathrm{S}=0.3 \\
\text { Metal soaps (probably manganese carboxylates or added stearates as dispersing agents) }\end{array}$ \\
\hline & GA-BU & $\begin{array}{l}\text { Hematite }\left(\alpha-\mathrm{Fe}_{2} \mathrm{O}_{3}\right) \text {, magnetite }\left(\mathrm{Fe}_{3} \mathrm{O}_{4}\right) \text {, maghemite }\left(\nu-\mathrm{Fe}_{2} \mathrm{O}_{3}\right) \text {, manganese oxide } \\
\left(\mathrm{Mn}_{2} \mathrm{O}_{7}\right) \text {, mullite }\left(\mathrm{Al}_{6} \mathrm{Si}_{2} \mathrm{O}_{13}\right) \text {, quartz }\left(\alpha-\mathrm{SiO}_{2}\right) \text {, spinel }\left(\mathrm{MgAl}_{2} \mathrm{O}_{4}\right) \text {, calcite }\left(\mathrm{CaCO}_{3}\right)\end{array}$ & $\begin{array}{l}\text { Drying oil: } \mathrm{P} / \mathrm{S}=2.1, \mathrm{~A} / \mathrm{P}=1.1, \mathrm{O} / \mathrm{S}=0.1 \\
\text { Metal soaps (probably manganese carboxylates or added stearates as dispersing agents) }\end{array}$ \\
\hline & GR-BU & $\begin{array}{l}\text { Hematite }\left(\alpha-\mathrm{Fe}_{2} \mathrm{O}_{3}\right) \text {, pyrolusite }\left(\mathrm{MnO}_{2}\right) \text {, anorthoclase }\left[(\mathrm{Na}, \mathrm{K}) \mathrm{AlSi}_{3} \mathrm{O}_{8}\right] \text {, wollastonite } \\
\left(\mathrm{CaSiO}_{3}\right) \text {, magnesium silicate, quartz }\left(\alpha-\mathrm{SiO}_{2}\right) \text {, calcium phosphate }\left[\mathrm{Ca}_{3}\left(\mathrm{PO}_{4}\right)_{2}\right] \text {, calcite } \\
\left(\mathrm{CaCO}_{3}\right)\end{array}$ & $\begin{array}{l}\text { Drying oil: } \mathrm{P} / \mathrm{S}=0.9, \mathrm{~A} / \mathrm{P}=1.8, \mathrm{O} / \mathrm{S}=0.1 \\
\text { Metal soaps (probably manganese carboxylates or added stearates as dispersing agents) }\end{array}$ \\
\hline & SP-BU & $\begin{array}{l}\text { Hematite }\left(\alpha-\mathrm{Fe}_{2} \mathrm{O}_{3}\right) \text {, goethite }[\alpha-\mathrm{FeO}(\mathrm{OH})], \text { manganese oxides, sanidine } \\
{\left[(\mathrm{K}, \mathrm{Na})(\mathrm{Si}, \mathrm{Al})_{4} \mathrm{O}_{8}\right] \text {, silicon oxide }\left(\mathrm{SiO}_{2}\right) \text {, anorthite }\left(\mathrm{CaAl}_{2} \mathrm{Si}_{2} \mathrm{O}_{8}\right) \text {, dolomite }\left[\mathrm{CaMg}\left(\mathrm{CO}_{3}\right)_{2}\right] \text {, }} \\
\text { calcite }\left(\mathrm{CaCO}_{3}\right) \text {, calcium phosphate }\left[\mathrm{Ca}_{3}\left(\mathrm{PO}_{4}\right)_{2}\right]\end{array}$ & $\begin{array}{l}\text { Drying oil: } \mathrm{P} / \mathrm{S}=2.1, \mathrm{~A} / \mathrm{P}=1.0, \mathrm{O} / \mathrm{S}<0.1 \\
\text { Metal soaps (probably manganese carboxylates or added stearates as dispersing agents) }\end{array}$ \\
\hline
\end{tabular}

* XRD, FT-IR-ATR and EDX analysis

** GC-MS and FT-IR-ATR analysis 
Table 3 - Results from SEM/EDX analysis (semiquantitative weight \%, ZAF matrix correction)

\begin{tabular}{|c|c|c|c|c|c|c|c|c|c|c|c|c|c|c|c|}
\hline Sample & Fe & Mn & Ca & Si & K & S & P & Ti & Cl & Al & Mg & Na & Zn & V & O \\
\hline WN-RU & 16.3 & 6.5 & 15 & 4.8 & 0.3 & 0.8 & 2.7 & 0.1 & 0.1 & 3.8 & 13.9 & 0.3 & - & - & 35.5 \\
\hline GA-RU & 29.9 & 3.2 & 1.1 & 16.5 & 0.8 & 0.3 & 0.6 & 0.3 & 0.1 & 8.1 & 0.8 & 0.2 & 0.1 & - & 38.1 \\
\hline GR-RU & 35.3 & 6.6 & 15.8 & 7.0 & 0.4 & 0.2 & 0.6 & 0.1 & 0.1 & 2.1 & 1.2 & 0.3 & - & 0.1 & 30.4 \\
\hline \multicolumn{10}{|c|}{} \\
\hline WN-BU & 34.4 & 7.1 & 2.6 & 9.6 & 0.5 & 0.9 & 0.9 & 0.1 & - & 5.1 & 4.5 & 0.3 & - & - & 34.1 \\
\hline GA-BU & 38.7 & 6.2 & 2.2 & 12.6 & 0.5 & 0.3 & 0.7 & 0.1 & 0.1 & 3.0 & 1.7 & 0.4 & - & - & 33.6 \\
\hline GR-BU & 31.1 & 11.6 & 1.8 & 13.5 & 0.9 & 0.1 & 0.6 & 0.1 & 0.1 & 3.8 & 1.7 & 0.5 & 0.1 & - & 34.7 \\
\hline SP-BU & 25.8 & 5.6 & 2.1 & 17.1 & 1.2 & 0.2 & 0.7 & 0.1 & 0.1 & 5.7 & 1.5 & 2.4 & - & 0.1 & 37.7 \\
\hline
\end{tabular}

Table 4 - Correlation of A/P ratios, \%manganese and iron content and ultimate tensile strength

\begin{tabular}{|c|c|c|c|c|}
\hline Sample & $\mathbf{A} / \mathbf{P}$ & $\% \mathbf{M n}$ & $\% \mathbf{F e}$ & $\boldsymbol{\sigma}_{\text {TS }}$ (MPa) \\
\hline GR-RU & 1.8 & 6.6 & 35.3 & 0.24 \\
\hline GA-RU & 1.1 & 3.2 & 29.9 & 0.19 \\
\hline GR-BU & 1.8 & 11.6 & 31.1 & 0.94 \\
\hline GA-BU & 1.1 & 6.2 & 38.7 & 0.72 \\
\hline SP-BU & 1.0 & 5.6 & 25.8 & 0.37 \\
\hline
\end{tabular}


Table 5- Observations of Raw and Burnt umber films by optical microscope. before (section) and after mechanical test (fracture)

\begin{tabular}{|c|c|c|c|c|}
\hline \multicolumn{2}{|c|}{ SAMPLE } & \multicolumn{2}{|c|}{ LM } & OBSERVATIONS \\
\hline \multirow{3}{*}{$\begin{array}{l}\text { RAW } \\
\text { UMBER }\end{array}$} & WN-RU & & NOT TESTED & Dry and weak \\
\hline & GA-RU & & & $\begin{array}{l}\text { GA-RU presents soft and irregular } \\
\text { edges. Small and localized cracks } \\
\text { parallel to the direction of fracture } \\
\text { can also be observed. }\end{array}$ \\
\hline & GR-RU & & & $\begin{array}{l}\text { GR-RU presents soft and irregular } \\
\text { edges. } \\
\text { Several diffuse microfissures along } \\
\text { the surface as well as cracks } \\
\text { parallel to the direction of rupture } \\
\text { can also be observed. }\end{array}$ \\
\hline \multirow{2}{*}{$\begin{array}{l}\text { BURNT } \\
\text { UMBER }\end{array}$} & WN-BU & & NOT TESTED & Dry and weak \\
\hline & GA-BU & & & $\begin{array}{l}\text { GA-BU presents a fracture with } \\
\text { irregular edges }\end{array}$ \\
\hline & & & & \\
\hline
\end{tabular}




\begin{tabular}{|l|l|l|l|}
\hline GR-BU & & $\begin{array}{l}\text { GR-BU presents a sharp fracture } \\
\text { that is perpendicular to the } \\
\text { direction of tension. The edges are } \\
\text { extremely smooth and the } \\
\text { deformation is concentrated close } \\
\text { to the breaking area. }\end{array}$ \\
\hline SP-BU & & $\begin{array}{l}\text { SP-BU present irregular edges in } \\
\text { the fracture area and shiny areas } \\
\text { due to the separation of the binder } \\
\text { from the lipid inorganic component } \\
\text { can be observed. }\end{array}$ \\
\hline
\end{tabular}

